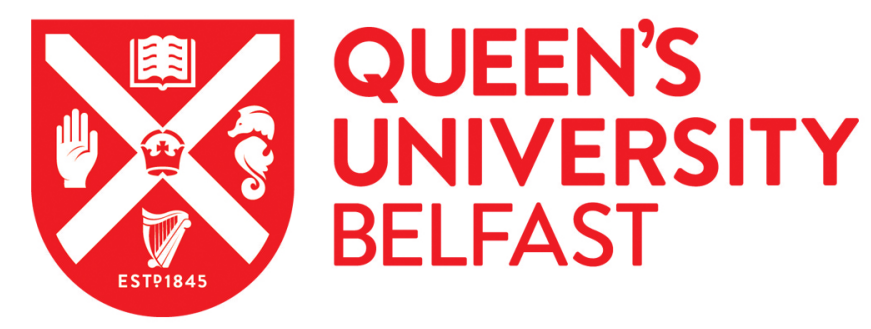

\title{
Is China's fifth-largest inland lake to dry-up? Incorporated hydrological and satellite-based methods for forecasting Hulun Lake water levels
}

Cai, Z., Jin, T., Li, C., Ofterdinger, U., Zhang, S., Ding, A., \& Li, J. (2016). Is China's fifth-largest inland lake to dry-up? Incorporated hydrological and satellite-based methods for forecasting Hulun Lake water levels. Advances in Water Resources. https://doi.org/10.1016/j.advwatres.2016.05.010

Published in:

Advances in Water Resources

Document Version:

Peer reviewed version

Queen's University Belfast - Research Portal:

Link to publication record in Queen's University Belfast Research Portal

Publisher rights

(c) 2016 Elsevier Ltd. This manuscript version is made available under the CC-BY-NC-ND 4.0 license http://creativecommons.org/licenses/by$\mathrm{nc}-\mathrm{nd} / 4.0 /$ which permits distribution and reproduction for non-commercial purposes, provided the author and source are cited.

\section{General rights}

Copyright for the publications made accessible via the Queen's University Belfast Research Portal is retained by the author(s) and / or other copyright owners and it is a condition of accessing these publications that users recognise and abide by the legal requirements associated with these rights.

Take down policy

The Research Portal is Queen's institutional repository that provides access to Queen's research output. Every effort has been made to ensure that content in the Research Portal does not infringe any person's rights, or applicable UK laws. If you discover content in the Research Portal that you believe breaches copyright or violates any law, please contact openaccess@qub.ac.uk. 


\section{Accepted Manuscript}

Is China's fifth-largest inland lake to dry-up? Incorporated hydrological and satellite-based methods for forecasting Hulun Lake water levels

Zuansi Cai , Taoyong Jin , Changyou Li , Ulrich Ofterdinger , Sheng Zhang, Aizhong Ding, Jiancheng Li

PII: S0309-1708(16)30139-7

DOI: 10.1016/j.advwatres.2016.05.010

Reference: ADWR 2619

To appear in: Advances in Water Resources

Received date: 15 April 2015

Revised date: 28 April 2016

Accepted date: 15 May 2016

Please cite this article as: Zuansi Cai, Taoyong Jin, Changyou Li, Ulrich Ofterdinger, Sheng Zhang, Aizhong Ding, Jiancheng Li , Is China's fifth-largest inland lake to dry-up? Incorporated hydrological and satellite-based methods for forecasting Hulun Lake water levels , Advances in Water Resources (2016), doi: 10.1016/j.advwatres.2016.05.010

This is a PDF file of an unedited manuscript that has been accepted for publication. As a service to our customers we are providing this early version of the manuscript. The manuscript will undergo copyediting, typesetting, and review of the resulting proof before it is published in its final form. Please note that during the production process errors may be discovered which could affect the content, and all legal disclaimers that apply to the journal pertain. 


\section{Highlights}

- Severe reduction of river discharge is the key factor behind the lake water decline.

- Water diversion project prevented a further water lever decline of $>0.5 \mathrm{~m}$ by 2012 .

- The water balance model can provide a useful tool to manage lake water resources. 


\title{
Is China's fifth-largest inland lake to dry-up? Incorporated hydrological and satellite-based methods for forecasting Hulun Lake water levels
}

\author{
Zuansi Cai ${ }^{1{ }^{*},}$, Taoyong Jin $^{2}$, Changyou $\mathrm{Li}^{3}$, Ulrich Ofterdinger ${ }^{1}$, Sheng Zhang ${ }^{3}$, Aizhong Ding ${ }^{4}$ \\ and Jiancheng $\mathrm{Li}^{2}$ \\ 'School of Planning, Architecture and Civil Engineering, Queen's University Belfast, Belfast BT9 5AG, \\ Northern Ireland, UK. \\ ${ }^{2}$ School of Geodesy and Geomatics, Wuhan University, Wuhan, 430079, China. \\ ${ }^{3}$ College of Water Conservancy and Civil Engineering, Inner Mongolia Agricultural University, Hohhot, \\ 010018, PR China. \\ ${ }^{4}$ College of Water Sciences, Beijing Normal University, Beijing 100875, PR China.
}

Abstract

Hulun Lake, China's fifth-largest inland lake, experienced severe declines in water level in the period of 2000-2010. This has prompted concerns whether the lake is drying up gradually. A multi-million US dollar engineering project to construct a water channel to transfer part of the river flow from a nearby river to maintain the water level was completed in August 2010. This study aimed to advance the understanding of the key processes controlling the lake water level variation over the last five decades, as well as investigate the impact of the river transfer engineering project on the water level. A water balance model was developed to investigate the lake water level variations over the last five decades, using hydrological and climatic data as well as satellite-based measurements and results from land surface modelling. The investigation reveals that the severe reduction of river discharge ($364 \pm 64 \mathrm{~mm} / \mathrm{yr}, \sim 70 \%$ of the five-decade average) into the lake was the key factor behind the decline of the lake water level between 2000 and 2010. The decline of river discharge was due to the reduction of total runoff from the lake watershed. This was a result of the reduction of soil moisture due to the decrease of precipitation $(-49 \pm 45 \mathrm{~mm} / \mathrm{yr})$ over this period. The water budget calculation suggests that the groundwater component from the surrounding lake area as well as surface run off from the un-gauged area surrounding the lake contributed $\sim$ net $210 \mathrm{Mm}^{3} / \mathrm{yr}$ (equivalent to $\sim 100 \mathrm{~mm} / \mathrm{yr}$ ) water inflows into the lake.

\footnotetext{
* Corresponding author: Zuansi Cai, School of Engineering and the Built Environment, Edinburgh Napier University, Merchiston Campus, Edinburgh EH10 5DT, Scotland, UK (z.cai@ napier.ac.uk)
} 
The results also show that the water diversion project did prevent a further water level decline of over $0.5 \mathrm{~m}$ by the end of 2012 . Overall, the monthly water balance model gave an excellent prediction of the lake water level fluctuation over the last five decades and can be a useful tool to manage lake water resources in the future. 


\section{Introduction}

Hulun Lake is the fifth-largest inland lake in China, which is located in northeast China close to the borders of China, Russia and Mongolia (Fig. 1). For many decades, the freshwater from the lake has sustained vast areas of wetlands which provide habitats for a variety of wildlife, including many species of fish and endangered migratory birds (e.g., Red-crowned Crane). The importance of Hulun Lake wetlands for the ecosystem has been recognised by international communities. In 2002, it was declared a Ramsar Wetlands of International Importance and chosen by UNSECO as a site for the World Network of Biosphere Reserves. However, the lake water level has been reported to have declined by approximately 4 metres over the last decade. The amount of river inflow into the lake has been reduced to approximately $40 \%$ of the five-decade average. This has resulted in the reduction of the total lake surface area by $>25 \%$ and total water volume by $>60 \%[1]$. The rapid decline of the lake water level has prompted concerns over whether the lake is disappearing gradually [2, 3]. The local government has recently spent several million US dollars on an engineering project to divert a river's flow into the lake, by constructing a canal linking a nearby river to the lake.

Fluctuations of the lake water level during the $20^{\text {th }}$ century as well as its impact on the lake ecosystem and the surrounding mining industries have attracted more attention from the academic community and local and regional water resource authorities for several decades. The historical and instrumental records show that during the last century the lake has experienced three wet (1900-1926, 1952-1964 and 1984-1999) and two dry (1927-1951 and 1965-1981) periods. The first and second wet periods brought the lake water level up from $537 \mathrm{~m}$ above sea level (asl) (less than $1 \mathrm{~m}$ in depth) in 1900 to a record level of $545.3 \mathrm{~m}$ asl in $1964[4,5]$. The rise of the water level during the second wet period increased the lake water discharge into the Dalaneluoumu River (Fig. 1) which endangered the mining industries alongside the river due to flooding. Thus, a number of dams were constructed by 
the local authorities to block the lake water discharge into the Dalaneluomu River in 1958 and as a consequence, the lake became a closed lake. As the lake water level continually rose and reached the record level of $545.3 \mathrm{~m}$ asl in 1964, concerns were raised about the potential flooding of nearby regions. A man-made water canal (Xinkai River, Fig.1) was then constructed in 1971 as a new outflow channel for the lake water discharge with a designed rate of $40.7 \mathrm{~m}^{3} / \mathrm{s}$ when the water level exceeds $544.8 \mathrm{~m}$ asl [6].

The second dry period of the lake in the last century, similar to the first one, caused a water level decline of approximately $3 \mathrm{~m}$ which began to attract scientific attention. Studies to investigate the link between climate change and the lake water level variation were conducted in the early 1990s. The reduction of river water discharge into the lake was identified as the key factor behind the observed water level decline $[4,5]$. Sediment core investigations conducted in order to construct the paleoclimate of the lake region suggested that the lake has experienced severe water level fluctuations since the late Glacial period [7]. In addition, studies of the lake water quality also raised concerns with regard to the eutrophication of the lake's water [8, 9]. The recent dry period which started in 1999 as well as the elevation of the mean temperature during the last two decades in the lake region has attracted more attention than previous dry periods. Further studies of the lake sediment cores have also been conducted to investigate the paleoclimate of the lake region to improve the understanding of recent climatic variations. The paleoclimate reconstruction suggested that in the recent 500 years the lake has expanded and the water salinity has decreased due to the warmer/and wetter weather conditions $[10,11]$. With the reduction of the river discharge into the lake, eutrophication became a major issue threatening the lake's ecosystem $[12,13]$ together with increased salinity [14]. Remote sensing data also revealed that the decline in water level increased the grassland degradation around the lake area during this period [15]. 
Despite the report of the severe decline of the lake water level over the last decade, research into the underlying processes has faced tremendous challenges due to the lack of in-situ lake water level measurements. This is because the hydrological station at Dalai (Fig. 1) which has provided daily water level measurements via an in-situ staff gauge since 1960 was discontinued from the early 1980s. There are some annual lake water level measurements from 1981 onwards which can be obtained from the local authorities, but the source of the data is unclear. Several studies have attempted to reconstruct the water level from the 1980s to early 2000 s using a water balance model approach (e.g., $[14,16])$, but the accuracy of the model prediction is difficult to assess without reliable water level measurements. However, studies over the last decade show that satellite radar altimetry can estimate water level time series with reasonable accuracy, which can provide an alternative to permanent gauging stations [17-21]. TOPEX/Poseidon (T/P) altimetry measurements have been reported to investigate six lake level variations including Hulun Lake during the period between 1993 and 2001 [22].

The objective of this study was to advance the understanding of key processes controlling the lake water level variations over thelast 50 years, and develop a quantitative tool to predict the lake water sources as well as assess the impact of the water diversion engineering project. This study conducted a comprehensive analysis of over 50 years of climatic and hydrological data obtained from the ground-based monitoring stations in the lake region. In addition to the ground-based data, satellite data as well as results from the Global Land Data Assimilation System (GLDAS) [23] were used to assess the changes of hydrological conditions within the $\sim 150,000 \mathrm{~km}^{2}$ lake watershed over the last two decades. These ground- and satellite-based observations, as well as the results from regional and continental modelling from a GLDAS land surface model, enabled us to conduct joint data analyses across both the lake regional and watershed scales. These combined data analyses helped to understand the impacts of climate change on the lake water level fluctuations as well as the hydrologic cycle across both scales. The conceptual 
understanding of the hydrological processes of the lake and its watershed support the development of a quantitative tool to model the lake water level variations over the past 50 years. The validated model was then used to assess the impact of the water transfer engineering project, since its construction, on the lake water level.

\section{Hulun Lake and its watershed}

\subsection{Hulun Lake and its hydrological system}

Hulun lake $\left(48^{\circ} 30^{\prime}-49^{\circ} 20^{\prime} \mathrm{N}, 117^{\circ} 00^{\prime}-117^{\circ} 41^{\prime} \mathrm{E}\right)$ is China's fifth-largest inland lake in surface area, which is located in the sparsely populated Hulun Buir Steppe of northeast China close to the borders of China, Russia and Mongolia (Fig. 1). The lake has an area of $2,000 \mathrm{~km}^{2}$ with an average water depth of 5-6 $\mathrm{m}$ and a maximum depth of approximately $8 \mathrm{~m}$. There are no settlements around the lake. The north-western side of the lake is surrounded by low mountains and hills of Mesozoic volcanic formations which form a fault-scarp lake shoreline, while broad lacustrine and alluvial plains are present along the southern and eastern shores of the lake. With the lake water level above $543 \mathrm{~m}$ asl, the lake water expands towards the south-eastern shoreline and forms an interconnected surface water body with the nearby Xinkai Lake (Fig. 1). The available hydrometric data show that at its highest water level record of $545.3 \mathrm{~m}$ asl in 1964 the lake formed an interconnected water body with the Xinkai Lake creating a lake surface area of $2,339 \mathrm{~km}^{2}$ [6]. The general geological setting of the Hulun Lake region consists of the hard rocks in the low mountainous area to the north-western side of the lake, where groundwater discharges into the lake via the weathered fractured rock. On the southern and eastern side of the lake, the broad lacustrine and alluvial plains scattered with stable and semi-stable dunes form the unconfined aquifers.

Hulun Lake, with a watershed area of approximately $150,000 \mathrm{~km}^{2}$, is fed by over 60 rivers and streams, but mainly by two major river systems: the Kherlen River and Wuerxun River 
(Fig. 2). The Kherlen River is one of the biggest rivers in Eastern Mongolia within the Pacific basin. The river takes its origin in the upper parts of the Khentii mountain range and flows to the south, and then gradually to the east and ultimately joins Hulun Lake in China. The river length is about $1,296 \mathrm{~km}$, with approximately $1,090 \mathrm{~km}$ in the territory of Mongolia and the rest in China. The river watershed area is approximately $100,000 \mathrm{~km}^{2}$ and is located mainly in Mongolia (Fig. 2). The Wuerxun River is a part of the hydrological system of the Halaha (Khalkha) River and Bear (Buir) Lake (Fig.1). The Halaha River is an upstream river of the Wuerxun River. The river takes its origin in the Daxing'an (Greater Khingan) mountain range of northeast China and flows to the northwest into the Bear Lake. The length of the Halaha River is about $233 \mathrm{~km}$, with a river basin of approximately $17,000 \mathrm{~km}^{2}$. The Bear Lake has an area of $600 \mathrm{~km}^{2}$. Water discharged from the lake flows into the Wuerxun River and continues to Hulun Lake in the north. The total watershed area of the Halaha River, Bear Lake and Wuerxun River is about $40,000 \mathrm{~km}^{2}$ (Fig. 2). The Dalaneluomu River has been the main outflow river of Hulun Lake, with a river length of $23 \mathrm{~km}$. The river was blocked by several man-made dams constructed in 1961. A man-made water canal (Xinkai River) was constructed in 1971 to allow for lake water discharge when the water level exceeds $544.8 \mathrm{~m}$ asl (Fig. 1). Due to the decline of the water level, there has been no outflow from the lake since 2000.

\subsection{Climate and land cover of the lake watershed}

The lake is located in a semi-arid region under the influence of a continental monsoon climate $[6,10,11]$. Precipitation mainly takes place from June to September. The mean annual temperature is about $0^{\circ} \mathrm{C}$ with the highest temperature of the year in July and the lowest in January. Temperatures from November to March are sub-zero and the lake is covered by up to $1.3 \mathrm{~m}$ of ice during this period. The area surrounding the lake (Fig. 1) is mainly covered by natural grass vegetation, which is known as steppe without any tall trees $[11,15]$. The Kherlen River basin is located in the cold semiarid environment of northeast 
Mongolia. The river basin has been the home of nomadic herders since time immemorial and remains a relatively pristine ecosystem. Mountain forest is the main land cover of the upstream of the basin, while grassland/steppe is the main cover of the downstream areas. It has been reported that the basin has an increased risk of desertification due to overgrazing and the decline of the surface and underground terrestrial water storage [24-26]. The climate and land cover of the Halaha River-Bear Lake-Wuerxun River Basin are similar to those of the lake region, except that land cover in the upstream of the basin is dominated by mountain forest.

\section{Date sources and approaches}

\subsection{Meteorological and Hydrological stations}

Data from four meteorological and hydrological stations each in the lake region were used in this study (Fig. 1). Meteorological data include daily precipitation, mean temperature, wind speed, relative humidity and sunshine duration from 1960 to 2014. Meteorological stations B \& C also include daily pan evaporation measurements over the period of 1960-2013, except some data are missing for the period between 1965 and 1974. Most of the evaporation measurements were carried out by the $\phi 20 \mathrm{~cm}$ pan evaporation instrument but since 2002 the evaporation measurements during the period from June to October of each year have been obtained by a large pan evaporation instrument (E601 evaporator with pan surface area of $300 \mathrm{~cm}^{2}$ ). Before 2002 there were three-year (from 1998 to 2001) pan evaporation measurements from both the $\phi 20 \mathrm{~cm}$ and the E601 evaporator for these months. Data from this period were used to estimate the conversion coefficient between the $\phi 20 \mathrm{~cm}$ pan evaporator and the E601 evaporator. The conversion coefficients of 0.60 and 0.56 were used to convert the E601 measurement into the $\phi 20 \mathrm{~cm}$ pan-evaporator measurements for meteorological stations B \& C, respectively. These coefficient values are within the reported values for this region $[27,28]$. 
The hydrological stations provide measurements for river discharge, evaporation and lake water level measurements on a daily basis. The Kherlen River and Wuerxun River were gauged at the hydrological station F, G \& H (Fig. 1). Due to limited river discharge measurements at hydrological station $\mathrm{H}$ (only 10-year annual measurements), river discharge measurements at hydrological station $\mathrm{G}$, which is located about $110 \mathrm{~km}$ upstream of the river mouth at the lake's south-eastern shoreline, were used to represent river discharge into the lake from the Wuerxun River. The river discharge measurements from hydrological station F, which is located about $20 \mathrm{~km}$ upstream of the river mouth at the lake's south shoreline, were used to represent river discharge into the lake from the Kherlen River. Hydrological station $\mathrm{E}$, which is located at the north-western shoreline, has daily lake water level measurements from 1961 to 1980 by an in-situ staff gauge as well as daily $\phi 20 \mathrm{~cm}$ pan evaporation data over this period. Hydrological station $\mathrm{F}$ has the $\phi 20 \mathrm{~cm}$ daily panevaporation measurements for 1996-2012, and similar measurements are also available from Hydrological station G for 1966-2012. The detailed data from meteorological and hydrological stations selected for this study are summarised in Table 1.

\subsection{Satellite altimetry data}

Studies over the last decade show that satellite radar altimetry can estimate lake water level time series with a reasonable accuracy, which could provide an alternative to permanent insitu gauging stations [18-22]. In this study, we used the multi-satellite altimetry dataset of the Radar Altimeter Database System (RADS). The datasets were established by the Delft Institute for Earth-Oriented Space Research (DEOS) at the Delft University of Technology, which provide different orbit altitudes and geophysical corrections to estimate sea-level measurements with higher accuracy [29, 30]. The RADS datasets contain eight satellite altimeter missions across Hulun Lake, including four types of repeat orbit data and two types of geodetic data from Topex/Poseidon (T/P), Jason-1, Jason-2, ERS-2, Envisat, Saral, GFO and Cryosat-2. However, only three cycles of ERS-2 had valid lake water level measurements. Special editing criteria, for example the distance to the lake shoreline, the 
altimeter range measurements and the valid number of waveforms in $1 \mathrm{~Hz}$ measurement, were used to extract measurements over the lake. Geophysical corrections related to the troposphere, ionosphere, earth tide and pole tide were applied before computing the lake water level with reference to the ellipsoid. The reference frame offsets between other satellites and T/P provided by RADS were applied to achieve the consistent time series of the lake water level. The lake water level variations were calculated by subtracting the EGM08 geoid height, and the bias between the Chinese National Height Datum.

Geophysical corrections applied in this study are detailed in Table S.1 in the supplement. These correction approaches were mainly recommended by a recent study, which investigated errors present in geophysical corrections for the inland water level estimated by satellite altimeter measurements [31]. The study revealed that the tropospheric and ionospheric corrections contributed main errors up to several centimetres by RADS. However, the accuracy of the water level estimates could be improved by using appropriate correction approaches, which include: 1) Model-derived tropospheric corrections from European Centre for Medium-Range Weather Forecasts (ECMWF) Re-analysis ERA Interim; 2) Radiometer measurements for wet tropospheric corrections only when these measurements are in the central parts of large lakes; 3) the Jet Propulsion Laboratory global ionosphere map (GIM) model for the ionospheric correction. With the accuracy less than several centimetres, the lake water levels estimated by RADS are sufficiently accurate to the purpose of this study.

By averaging valid satellite measurements in each month, the monthly lake water level time series over the period from November 1992 to December 2014 (266 months in total) was obtained. The robust outlier detection technique known as Hampel X84 [32] was used to detect the gross errors of all measurements in each month (the detail of the Hampel X84 technique is described in the Appendix). The main purpose of the Hampel X84 technique was to eliminate/minimise the impact of the temporal and spatial measurements from the 
multi-satellite altimeter missions on the monthly lake level estimates. Overall, we found 4,373 valid satellite observations over Hulun Lake. The measurements covered 244 months of this period, and each month contains 3-52 valid observations over Hulun Lake. During the period (266 months in total), there were 22 months without valid satellite measurements. These were July 1998, Feb 1999, April 2003, December 2006, November 2008, January, April \& December 2009, April 2010, March, November \& December 2011, March, April, November \& December 2012, December 2013, and January - April and December 2014.

\subsection{Data from the GLDAS Land Surface model}

Noah is a land surface model which has been developed since the 1990 s and has continually benefited from a steady progression of improvement [33,34]. Noah is one of four land surface models in the Global Land Data Assimilation System (GLADS) [23]. Data used in this study (red box in Fig. 2) were precipitation, total evapotranspiration, soil moisture, snow water equivalence, snowfall, snowmelt, and total canopy water storage as well as surface and subsurface runoff simulated from the Noah 2.7.1 model. These data with others are archived and distributed by the Goddard Earth Sciences Data and Information Services Centre. The data have a resolution of 1.0 degree and range from 1979 to the present. The soil moisture data contain the depth-averaged amount of water present in the specific soil layer beneath the surface. In the Noah model there are four soil layers which are located 00.1 m, 0.1-0.4 m, 0.4-1.0 $\mathrm{m}$ and 1.0 -2.0 $\mathrm{m}$ below land surface. The Noah model simulation was forced by combination of NOAA/GDAS atmospheric analysis fields, spatially and temporally disaggregated NOAA Climate Prediction Center Merged Analysis of Precipitation fields, and observations based on downward shortwave and longwave radiation fields derived using the method of the Air Force Weather Agency's AGRicultural METeorological modelling system (AGRMET). The simulation was initialized on 1 January 1979 using soil moisture and other state fields from a GLDAS/Noah climatology model for that day of the year. 


\subsection{Terrestrial Water Storage}

Terrestrial water storage (TWS) defines all forms of water stored above and beneath the land surfaces of the Earth, including soil moisture, snow and ice, groundwater, surface water, and water contained in biomass. In general, change in TWS can be computed as:

$$
\Delta T W S=\Delta S M+\Delta S N W E+\Delta T C W S+\Delta S W+\Delta G W
$$

where SM is soil moisture, SNWE is snow water equivalent, TCWS is total canopy water storage, GW is groundwater and SW is surface water. In this study, $\Delta T W S$ and its individual components are presented as annual equivalent water thickness (EWT) anomalies in a time series. The annual anomaly value of a variable is the average of monthly anomaly values during the year, which represent their deviations from the mean value of the respective variable over the reference period (January 2004 through December 2009). $\Delta T W S$ within the Hulun Lake watershed approximated by the red box in Fig. 2 was characterised by Gravity Recovery and Climate Experiment (GRACE) data-Based on precise measurements of the Earth's gravitational field, GRACE provides monthly variations in TWS since April 2002 [35, 36]. $\triangle S M, \triangle S N W E, \triangle T C W S$ and $\triangle S W$ were obtained from the GLDAS/Noah model. For the purpose of this investigation, these four individual components were summed, with the sum hereafter referred to as soil, snow, canopy and surface water anomaly $(\triangle \operatorname{SSCSW})$. As the soil depth in the GLDAS/Noah is $200 \mathrm{~cm}$, SM contributions from deep soil layers were not accounted for.

In this study, we used GRACE mass concentration (mascon) solutions provided by Jet Propulsion Laboratory (JPL). These datasets are available at the Physical Oceanography Distributed Active Archive Centre and GRACE Tellus websites. The mascon solutions are referred to as JPL RL05.1M, and derived from solving for monthly gravitational field variations in terms of spherical cap mass concentration functions. Realistic geophysical information was introduced during the solution inversion to intrinsically remove correlated error. Thus, these mascon solutions do not need to be destriped or smoothed, and show 
less suffering from leakage errors than spherical harmonic solutions [37]. The JPL RL05.1M mascon solutions have a $0.5^{\circ} \times 0.5^{\circ}$ sampling resolution of global water storage anomalies relative to a time-mean from 2004 to 2009 from global $3^{\circ}$ equal-area spherical cap mascons. There are about four $3^{\circ}$ mascons within the $3^{\circ} \times 13^{\circ}$ grid box (Fig.2) which was used to investigate $\triangle T W S$ within the Hulun lake watershed. In this study, a total of $1560.5^{\circ} \times 0.5^{\circ}$ JPL RL05.1M mascon solutions within the Hulun watershed were extracted, and then modified with their corresponding "gain" factors which were obtained by a least-square fit to a hydrology model [37]. Statistical analysis of these 0.5 degree mascon solutions using the arithmetic average and standard deviation approaches was conducted to obtain the annual mean $\triangle T W S$ time series as well as the variance.

\subsection{Lake Water Balance Model}

The general lake water balance for a period of the time interval can be expressed as:

$$
\frac{\Delta V}{\Delta t}=Q_{\text {in }}-Q_{\text {out }}
$$

where $\frac{\Delta V}{\Delta t}$ is the change of the lake's water volume $\left(\Delta V, L^{3}\right)$ over a period of time interval $(\Delta t, T), Q_{\text {in }}$ is any kind of water inflow rate $\left(L^{3} / T\right)$ into the lake including precipitation, river discharge, groundwater discharge into the lake, surface runoff from the area surrounding the lake, etc. $Q_{\text {out }}$ is any kind of water outflow rate $\left(L^{3} / T\right)$ from the lake including evaporation, surface water discharge \& groundwater recharge from the lake, etc. Changes in lake water volume can also be expressed in terms of the relative changes in the elevation of the lake water level, as follows:

$$
\frac{\Delta h}{\Delta t}=\frac{\Delta V}{\Delta t \cdot A(h)}=\frac{Q_{\text {in }}-Q_{o u t}}{A(h)}
$$

where $\frac{\Delta h}{\Delta t}$ is the change of the lake water level $(h, L)$ for a period of time interval and $A(h)$ is the lake water surface area $\left(L^{2}\right)$ which is expressed as a function of the water depthdependent surface area of the lake. 
In this case, water inflow into Hulun Lake includes direct precipitation into the lake surface water area, discharge from the Kherlen River and Wuerxun River, and groundwater discharge from the area surrounding the lake, as well as river discharge and surface water runoff from the un-gauged area surrounding the lake. Since the two gauging stations at the Kherlen and Wuerxun Rivers are about 20 and $110 \mathrm{~km}$ upstream of the river mouths at the lake, in addition to $\sim 60$ un-gauged streams, there is a considerable un-gaugedarea surrounding the lake $\left(\sim 16,000 \mathrm{~km}^{2}\right)$ (Fig. 1) which contributes river discharges and surface runoff into the lake. Water outflow from the lake includes evaporation from the lake surface water area and groundwater recharge by seepage. Due to the annual lake water abstraction for industrial and domestic consumption being below $2 \%\left(27 \mathrm{M} \mathrm{m}^{3} / \mathrm{yr}[6,12]\right)$ of the annual river inflow, the lake's water consumption is not accounted for in the water balance calculation. The water outflow also includes lake water outflow via the man-made water canal (Xinkai River, Fig. 1), which was constructed in 1971 with a designed outflow rate of $40.7 \mathrm{~m}^{3} / \mathrm{s}$ when the lake water level exceeds $544.8 \mathrm{~m}$ asl $[6,16]$. Water balance calculations for this study used data from the instrumental records which mainly began after 1960. Thus, the water balance for Hulun Lake over a time interval $(\Delta t)$ can be calculated as:

$$
\frac{h(t)-h(t-\Delta t)}{\Delta t}=P(\Delta t)-E(\Delta t)+\frac{Q_{r, i n}(\Delta t)}{A(\bar{h})}-\frac{Q_{l, o u t}(\Delta t)}{A(\bar{h})}+\frac{Q_{s, u g, i n}(\Delta t)}{A(\bar{h})}+\frac{Q_{g w, n e t}}{A(\bar{h})}
$$

where $P$ is precipitation into the lake water surface $\left(L^{3} L^{-2}\right) ; E$ is the evaporation from the lake water surface $\left(L^{3} L^{-2}\right) ; A(\bar{h})$ is the lake surface water area at the average lake water level within the time interval $\Delta t ; Q_{r, i n}$ is the sum of river discharges from the Kherlen and Wuerxun Rivers into the lake; $Q_{l, o u t}$ is the lake water outflow rate into the Xinhai River; $Q_{s, u g, \text { in }}$ is the surface water inflow rate including river discharge and surface water runoff from the un-gauged area surrounding the lake (Fig. 1), and $Q_{g w, n e t}$ is the net groundwater exchange between the lake and its surrounding aquifers. Eq. (4) has two unknown parameters of $h(t)$ and $A(\bar{h})$. To simplify the calculation, the average lake surface area 
during the time step $A(\bar{h})$ is approximated by the surface area of the previous time step $A(h(t-\Delta t))$. With the consideration of measurement errors, Eq. (4) is revised by including the model residue $\varepsilon$, as follows:

$\frac{h(t)-h(t-\Delta t)}{\Delta t}=P(\Delta t)-E(\Delta t)+\frac{Q_{r, i n}(\Delta t)}{A(h(t-\Delta t))}-\frac{Q_{l, o u t}(\Delta t)}{A(h(t-\Delta t))}+\frac{Q_{s, u g, i n}(\Delta t)}{A(h(t-\Delta t)}+\frac{Q_{g w, n e t}}{A(h(t-\Delta t)}+\varepsilon(\Delta t)$

Each term on the right-hand side of Eq. (5) is represented by a water flux rate. Therefore, Eq. (5) can be further simplified as:

$\frac{\Delta h}{\Delta t}=P(\Delta t)-E(\Delta t)+R_{r, \text { in }}(\Delta t)-R_{l, o u t}(\Delta t)+R_{s, u g, \text { in }}(\Delta t)+R_{g w, n e t}(\Delta t)+\varepsilon(\Delta t)$

where $R_{r, \text { in }}$ represents the lake water influx rate via river discharge $\left(L^{3} L^{-2} T^{1}\right), R_{l, \text { out }}$ represents the lake water out-flux rate via surface water outflow into the Xincai River $\left(L^{3} L^{-2}\right.$ $\left.T^{-1}\right), R_{s, u g, \text { in }}$ represents the lake influx rate from the un-gauged area surrounding the lake $\left(L^{3}\right.$ $\left.L^{-2} T^{1}\right) ; R_{g w, n e t}$ represents the net flux rate via groundwater exchange between the lake and its surrounding aquifers $\left(L^{3} L^{-2} T^{1}\right)$.

The lake water balance model performance was evaluated using the Nash-Sutcliffe model efficiency index (EF, [38]):

$$
E F_{n}=\frac{\sum_{i=1}^{n}\left(h_{i}-\bar{h}\right)^{2}-\sum_{i=1}^{n}\left(\widehat{h}_{i}-h_{i}\right)^{2}}{\sum_{i=1}^{n}\left(h_{i}-\bar{h}\right)^{2}}
$$

where $n$ is the number of observations $(-), h_{i}$ is the observed lake level $(L), \overline{h_{l}}$ is the mean observed lake level $(L)$ and $\widehat{h_{l}}$ is the simulated lake water level $(L)$. In this study, model performance evaluation was conducted using monthly observed and predicted lake levels in Eq. (7). The observed water levels were obtained either from the the in-situ gauging station at hydrological station $\mathrm{E}$ or from the satellite altimetry data. 


\section{Results \& Discussions}

\subsection{Lake water level fluctuations}

Fig. 3 shows the hydrological data of Hulun Lake over the last five decades, including the lake water level (above sea level), precipitation, pan-evaporation and river influx rate. The annual water levels from 1960 to 1980 presented in Fig. 3a are the averages of daily measurements from an in-situ gauging station at hydrological station $\mathrm{E}$. There are two data sources for the lake water level after the discontinuation of hydrological station $E$ in the early 1980s: 1) Reported annual level from a local authority for the period between 1981 and 2009 [9]. The source and accuracy of these data are unclear as the details of the measurements are unknown. Unofficial reports suggest that these water levels were likely estimated from the previous developed relationship between the water level and the surface area, where the lake surface areas were estimated from satellite images; 2) Annual water levels from the satellite altimetry measurements from 1993 to 2014 . These are the average of the monthly measurements of each year. Precipitation includes rainfall and snowfall. Pan-evaporation is the mean available measurements from the meteorological and hydrological stations surrounding the lake area (Table 1), without considering the spatial weighting factor of each station. The river influx rate is the sum of the river discharges of the Kherlen River and Wuerxun River which is normalised to the lake surface area of $2,000 \mathrm{~km}^{2}$ (equivalent to the water level of $\sim 543 \mathrm{~m}$ asl). The river discharges of both rivers are gauged at hydrological stations F \& G, respectively (Table 1 \& Fig. 1).

The lake water level data (Fig. 3a) show that the reported lake water levels and those obtained from the satellite altimetry observations follow a similar trend during the period of 1993-2009. Most of the reported lake levels during this period are within the uncertainty ranges of the satellite altimetry measurements. The good agreement between the lake water levels obtained from two independent approaches increased the confidence of the satellite lake water level measurements for Hulun Lake. In addition, the satellite altimetry observations were used in numerous studies (e.g., $[17,21])$ to determine sea and lake water 
levels, which confirmed that the approach can provide an alternative to the in-situ permanent gauging station to estimate the water level time series. The results also show that the lake water level measured by the satellite altimeter was $541.2 \mathrm{~m}$ asl in 2009 which is $1 \mathrm{~m}$ higher than the reported water level in that year. The lake water level in the following years (20102014) measured by the satellite altimeter shows that the satellite measurements in 2009 are consistent with those in the following year, with no single monthly measurements near to the reported water level of $540.2 \mathrm{~m}$ asl. In addition, our ground-based measurements of the lake water level in 2008-2009 also show that satellite measurement in 2009 was closer to these snapshot measurements. This suggests that the reported lake water level in 2009 is likely inaccurate.

The lake water level and precipitation data over the last five decades (Fig. 3a \& b) show that there were two dry periods (1960-1981 and 1999-2012) and one wet period (1982-1998) in the lake region over the period. The first dry period (1965-1981) caused the water level decline of $\sim 3 \mathrm{~m}$ (from 545 to $542 \mathrm{~m}$ asl). The average precipitation during this period was $273 \mathrm{~mm} / \mathrm{yr}$ which is a bit below the five-decade average $(290 \mathrm{~mm} / \mathrm{yr})$, despite only 6 years of the 22-year period having an annual precipitation rate above the five-decade average. The second dry period took place between 1999 and 2012 which brought the water level down from $545 \mathrm{~m}$ asl in 1999 to $541 \mathrm{~m}$ asl in 2012. The average precipitation of this period was $240 \mathrm{~mm} / \mathrm{yr}$ which is $50 \mathrm{~mm} / \mathrm{yr}$ below the five-decade average. During the 13-year dry period, there were only 2 years with an annual precipitation slightly above the five-decade average; the rest of the period was below the average. A study of drought variability in the region suggested that the severe drought from 1999 to 2012 was associated with large-scale climate forces such as the El Nino-Southern Oscillation, the Pacific Decadal Oscillation and the summer North Atlantic Oscillation [39]. The wet period between 1982 and 1998 brought the lake water level up from $543 \mathrm{~m}$ asl in 1982 to above $545 \mathrm{~m}$ asl in 1985 . The lake water level then remained at this level for the rest of the period. During this wet period, the average precipitation was $330 \mathrm{~mm} / \mathrm{yr}$ which is $40 \mathrm{~mm} / \mathrm{yr}$ higher than the five-decade average. 
Precipitation varied significantly over this period, with the lowest rate of $140 \mathrm{~mm} / \mathrm{yr}$ in 1986 and the highest rate of $570 \mathrm{~mm} / \mathrm{yr}$ in 1998. Statistical analysis of the five-decade monthly data (Fig. S.1a in the supplement) indicates that over $80 \%$ of annual precipitation occurs from June to September with approximately $45 \%$ in July and August.

Pan-evaporation measurements (Fig. 3c) show that evaporation in the lake region was rather stable over the last five decades, except a continuous decrease in the recent 6 consecutive years (2008-2013). Mean evaporations for the two dry periods and the wet period were 1644, 1637 and $1645 \mathrm{~mm} / \mathrm{yr}$ which are close/equal to the five-decade average of $1645 \mathrm{~mm} / \mathrm{yr}$. This suggests that lake evaporation had very limited impact on the lake water level variations over the last five decades. Unlike evaporation, river water inflow data (Fig. 3d) show three distinguished patterns for the one wet and two dry periods. During the first dry period, there was a relatively stable river discharge period with a mean influx rate of $500 \mathrm{~mm} / \mathrm{yr}$, close to the five-decade average $(507 \mathrm{~m} / \mathrm{yr})$, which mirrors the precipitation of the period. A rather fluctuating river discharge followed during the wet period. The mean river influx rate of this wet period was $750 \mathrm{~mm} / \mathrm{yr}$ which is $\sim 250 \mathrm{~mm} / \mathrm{yr}$ higher than the fivedecade average. During the second dry period, a continuous decrease of the river discharge was observed for 13 consecutive years (2000-2012), with an annual river influx rate below the five-decade average from 190 to $450 \mathrm{~mm} / \mathrm{yr}$. The mean river influx rate for this period was $200 \mathrm{~mm} / \mathrm{yr}$ which is $<40 \%$ of the five-decade average. With the mean precipitation rate below the five-decade average of $50 \mathrm{~mm} / \mathrm{yr}(\sim 17 \%$ of the five-decade average of $507 \mathrm{~mm} / \mathrm{yr}$ ), the amount of river discharge reduction over this dry period was disproportionate to the reduction of the precipitation rate. In addition, the increase of river discharge during the wet period (50\% of the five-decade average) was also disproportionate to the increase of precipitation (12\% of the average). The river discharge patterns within both the wet and the second dry periods suggest that surface runoff in the lake watershed is sensitive to a change of precipitation. Monthly statistical analysis also shows that over $85 \%$ of the annual pan evaporation occurs from April to September with over $50 \%$ from May to 
July. Unlike the precipitation where $50 \%$ of it occurs in July and August, the peak river discharge rates are generally found in August and October which contribute $\sim 45 \%$ of the annual river discharge (Fig. S.1a in the supplement). This is probably due to the lag time of the rain falling on the lake watershed to its discharge at the gauging stations.

\subsection{Climate change and its impact on evaporation}

Daily measurements of mean temperature, relative humidity, wind speed and sunshine duration from the four meteorological stations in the lake region are presented in Fig. 4. The selection of these four meteorological measurements for this study was based on their impact on evaporation from the lake. The temperature data (Fig. 4a) show that the fivedecade average temperature was $-0.01^{\circ} \mathrm{C}$ with one warm and two cold periods. The first cold period took place from 1960 to 1988 with a mean temperature of $-0.65^{\circ} \mathrm{C}$. Within the 29 year cold period, there were 24 years with an annual temperature below the 55-year average. The warm period in the lake region took place from 1989 to 2008, with 20 consecutive years with an annual temperature above the five-decade average. The mean temperature of this warm period was $0.95^{\circ} \mathrm{C}$. The second cold period took place from 2009 to 2013 , with a mean temperature of $-0.36^{\circ} \mathrm{C}$. The joint analysis of temperature and precipitation over the last five decades did not show a clear correlation between the changes of the two measurements.

The annual relative humidity over the last five decades was rather stable, with a mean average of $64 \%$ and a variation of $\pm 6 \%$. There were 10 consecutive years (2003-2012) with annual humidity below the five-decade average followed by an increase in 2013 but a decrease in 2014 (Fig. 4b). The annual wind speed fluctuated over the five-decade data record (Fig. 4c). The wind speeds in all years of the first dry period were higher than the fivedecade average of $3.5 \mathrm{~m} / \mathrm{s}$, with a mean value of $0.4 \mathrm{~m} / \mathrm{s}$ above the average. However, the wind speed reduced to below or equal to the five-decade average from 1981 onwards, with an average of $3.2 \mathrm{~m} / \mathrm{s}$ for this period. The variation of the wind speed at the four meteorological stations also decreased from 1981 but gradually increased after 2002. Similar to the wind speed, overall sunshine duration in the first dry period was slightly higher 
than the five-decade average but the rest of the period was below the average. The combined analysis of the annual precipitation against the annual relative humidity, wind speed and sunshine duration did not show clear correlations among these measurements.

Monthly climatic data show that temperature in the lake region is sub-zero from November to March with an average of approximately $-20^{\circ} \mathrm{C}$ and a January average of approximately $24^{\circ} \mathrm{C}$. Due to the sub-zero temperature from November to March, the pan evaporation remains low in this period. The peak of pan evaporation of the year is found in May and June. This is probably due to the relatively warm temperature $\left(12-18^{\circ} \mathrm{C}\right)$ and the long sunshine duration in these two months as well as the high wind speed. The low relative humidity of this time of year may also play a key role in accelerating the evaporation rate (Fig. S. 1 in the supplement). However, the linear regressions of the four annual climatic measurements (annual temperature, relative humidity, wind speed and sunshine duration) and panevaporation at meteorological stations B \& C showed very weak correlations $(-0.19 \leq r \leq$ $0.19)$ between the pan evaporation and the climate variations over the last five decades. The recent 6-consecutive-year decrease (2009-2013) of the pan evaporation with the annual rate below the 54-year average up to $490 \mathrm{~mm} / \mathrm{yr}$ suggests that further studies using other approaches (e.g., the physical-based mass and energy balances [40]) are needed to better understand the impact of climate change on the variations of pan evaporation. With a magnitude of change in lake evaporation over recent years similar to the annual precipitation rate, this could result in significant changes in key hydrologic components of the lake as well as the lake water quality.

\subsection{Hydrologic cycle within the lake watershed}

In the above analyses, river discharge within the lake watershed displayed sensitivity to changes in precipitation. In addition to changes in precipitation, the annual temperature in the lake region fluctuated by $4^{\circ} \mathrm{C}$ over the last five decades (Fig. $\left.4 \mathrm{a}\right)$. Changes in temperature and other climatic parameters can also cause changes in evapotranspiration and soil moisture leading to changes in land cover pattern, which could ultimately affect the 
surface runoff in the watershed. As river discharge is contributed from subsurface and surface runoff within the two relatively pristine river basins (Wuerxun and Kherlan), understanding the impact of climate change on the hydrologic cycle within the two river basins can help to identify the key drivers of changes in river discharge. The Global Land Data Assimilation System which consists of land surface models forced with land- and satellite-based observations is generating a series of high-resolution datasets regarding land surface forcing (e.g., precipitation), state (e.g., temperature and soil moisture) and flux (e.g., evapotranspiration) [23,34]. These observations and model predictions were used to investigate the land surface component of the hydrology cycle within the lake watershed in response to the climate change over the last few decades.

Fig. 5 shows the area's average runoff, precipitation, soil moisture, evapotranspiration, snow water equivalent, total canopy water storage, snowmelt and snowfall within the lake watershed over the last 24 years from the GLDAS/Noah model, as well as the observed runoff and precipitation measured at the local stations. The results show that overall the GLDAS/Noah model offers a fairly good prediction of the trend of total runoff within the watershed over the last 24 years (Fig. 5a). However, the model predictions are $\sim 50 \%$ lower than the local observations, with some discrepancies in the years 1980, 1981 and 1996. Due to the simulation being started from 1979 , the model initiation may play a big part in the observed errors for the years 1980 and 1981, while the extremely low precipitation rate used in the model simulation in 1996 could be the key factor behind the low predicted runoff in that year. However, it is important to recognise that the GLDAS/Noah model just considers the surface water and subsurface water interactions within the top $2 \mathrm{~m}$ soil zone below the land surface. Surface water interactions with the deeper soil layers (e.g., surface water and groundwater interactions) are not considered. This could contribute errors to the overall model predictions. The model's results also show that river discharge is significantly influenced by subsurface runoff from the soil zone. During the wet period (1981-1997) subsurface runoff contributed about $30 \%$ of river discharge. In contrast, during the second 
dry period (1999-2012) subsurface runoff reduced severely in 1999-2000 and eventually became zero after 2001. In addition to about two-thirds of the reductions of surface runoff, river discharge in this dry period decreased significantly to $\sim 20 \%$ of the wet period (Fig. 5a). High correlation (coefficient: 0.74 ) between the modelled total runoff and soil moisture within the lake watershed over the last 24 years, suggests that river discharge is dominated by changes in soil moisture.

Similar precipitation rates used in the GLDAS/Noah model and observed at the local stations (except 1996) suggested that the observed precipitation in the lake region can fairly represent the mean precipitation of the whole watershed over the last 24 years (Fig. 5b). Overall predicted evapotranspiration rates showed a similar trend to soil moisture from 1980 to 2007 , but there were some increases of evapotranspiration after 2008 (Fig. 5b). The recent increase of evapotranspiration is likely a result of the increased soil moisture in the top three soil layers $(0-0.1,0.1-0.4$ and $0.4-1 \mathrm{~m})$ due to the slight increase of precipitation (Fig. 5b-c). The increased available water moisture provides additional water for plant transpiration where grassland is the main vegetation cover within the watershed. Despite an increase of soil moisture in the top soil layers, the soil moisture in the bottom soil layer (1-2 m) remained at a low level (Fig. 5c). This implies that the groundwater level within the watershed has not recovered despite the recent increase of precipitation. As a result of this, there were no increases of the subsurface runoff within the watershed accordingly (Fig. 5a). The GLDAS/Noah model also showed that the snowfall/melt and canopy have very limited impact on the water storage within the lake watershed, as these water components are over an order of magnitude less than soil moisture (Fig $5 c-d)$. Overall, data from the GLDAS/Noah model revealed that the severe reduction of river discharge from 2000 onward was a result of the reduction in subsurface and surface runoff due to the depletion of soil moisture.

\subsection{Changes in terrestrial water storage}

Fig. 6 shows annual $\triangle T W S$ and $\triangle S S C S W$ within the Hulun lake watershed from 1980. Over the period of 2002-2014, both $\triangle T W S$ from GRACE and $\triangle S S C S W$ from the GLDAS/Noah 
model showed a similar trend of changes in terrestrial water storage. Changes in water storage determined by these two independent approaches are in the same range within their uncertainties, despite the GLDAS/Noah method not considering changes in water storage below the top $2 \mathrm{~m}$ soil layer and surface water storage. This suggested that changes in water storage in deeper soil layers and aquifers within the watershed were insignificant during this period. Furthermore, surface water storage changes might contribute insignificantly to $\triangle T W S$ estimated by GRACE. Overall, the annual $\triangle T W S$ and $\triangle S S C S W$ results suggested that $\triangle S S C S W$ could be used as an alternative to investigate changes in terrestrial water storage where GRACE measurements were not available. In fact, $\triangle S S C S W$ data showed a rapid decline of water storage in 1999-2001, which was consistent with observed river discharge (Fig. 3d). The lower average water storage during the period of 2002-2012 than those in the 1980s and 1990s within the lake watershed was consistent with studies which reported a decline in surface and underground terrestrial water storage from the late 1990s [3, 24].

We recognised that the use of GRACE and GLDAS/Noah data within the grid box instead of those within the actual lake watershed boundary could introduce uncertainties in interpreting changes of water storage within the lake watershed. This is due to the fact that the lake watershed is too small $\left(\sim 150,000 \mathrm{~km}^{2}\right)$, which is below GRACE data spatial resolution of $200,000 \mathrm{~km}^{2}$ (e.g, [41]). Furthermore, with a data resolution of $1^{\circ} \times 1^{\circ}$ from the GLDAS/Noah model, the lake watershed is too small to extract these data into such an irregular watershed boundary. Therefore, changes in water storage within the lake watershed were represented by those within a larger area of over $300,000 \mathrm{~km}^{2}$ of the $3^{\circ} \times 13^{\circ}$ grid box (Fig. 2). This representation also led to a part of the lake water body (>50\% lake with a surface area of $>1,000 \mathrm{~km}^{2}$ ) was included in the water storage estimates. The inclusion of the lake surface water storage could introduce errors in $\triangle T W S$ estimated by GRACE, as the nonuniform water storage distribution due to the localised lake water storage within the lake watershed can have impacts on GRACE watershed-based average water storage changes 
[41]. In addition, changes in surface water storage which was not considered in the GLDAS/Noah model could also lead to errors in the total water storage changes. Therefore, changes in water storage presented in Fig. 6 could be only used as proxies of those within the lake watershed.

\subsection{Lake water level modelling}

\subsubsection{Calibration of the lake model: the 1963-1980 period}

A monthly lake water balance was calibrated by using the measurements of the lake water level, river discharge and pan-evaporation from the years 1963-1980. During this period, the daily water level was measured by an in-situ gauging station at hydrological station $\mathrm{E}$. The average precipitation at the four meteorological stations in the lake region was used to represent the precipitation into the lake $(P)$. The pan-evaporation measurement at hydrological station $E$ was chosen to represent the lake's water evaporation $(E)$ with a conversion coefficient of 0.6088 which has been examined in previous studies $[14,16]$. This selection was based on the fact that hydrological station $E$ is located on the lake's shoreline. Statistical analysis showed that the monthly pan-evaporation at hydrological station E was $86.3 \%$ of the average of other available corresponding measurements from meteorological and hydrological stations, with a correlation coefficient $\left(R^{2}\right)$ of 0.96 over this period. River influx rate into the lake $\left(R_{r, i n}\right)$ is the sum of river discharges gauged at hydrological stations F \& G normalised to the lake surface area. A relationship between the lake water level and surface area developed by a previous study (Fig. S.2 in the supplement) $[6,42]$ was used to estimate the lake surface area. Over the 18-year calibration period, there were only 72 days with the water level above $544.8 \mathrm{~m}$ asl which induced the lake surface water discharge into the Xinkai River. These discharge events took place in June-October $1971(5,15,25,15,8$ days each). The lake water out-flux rates $\left(R_{l, \text { out }}\right)$ in these five months were calculated by the designed discharge rate of $40.7 \mathrm{~m}^{3} / \mathrm{s}$ according to the number of days in each month which were normalised to its corresponding lake area. As no measurements of the un-gauged 
surface water influx rate $\left(R_{s, u g, i n}\right)$ and the net groundwater influx rate $\left(R_{g w, n e t}\right)$ from the surrounding aquifers were taken, the impacts of these two water components on the lake water budget as well as the model residue $(\varepsilon)$ represented in the last three terms in Eq. (6) were lumped together into a calibration parameter $\gamma$. This approach is similar to a recent lake study in Argentina [43]. Thus, Eq. (6) can be re-written as follows, and was used for the model calibration.

$$
\gamma(\Delta t)=\frac{\Delta h}{\Delta t}-P(\Delta t)+E(\Delta t)-R_{r, \text { in }}(\Delta t)+R_{l, \text { out }}(\Delta t)
$$

Fig. 7 shows the calibration parameter value $(\gamma)$ and its monthly averages, as well as average monthly precipitation, evaporation, river influx and mean temperature over the 18year calibration period. The calibration results showed a clear trend of the monthly $\gamma$ value fluctuating over a year. The average monthly $\gamma$ value during winter months (DJF) of the year is flat and close to zero; then it increases substantially during spring months (MAM) and reaches its peak of the year $(\sim 130 \mathrm{~mm})$ in May. During summer months (JJA) the average $\gamma$ value decreases dramatically from the peak of $130 \mathrm{~mm}$ in May to $75 \mathrm{~mm}$ in June and further decreases to $\sim-55 \mathrm{~mm}$ in August. There are some increases of the $\gamma$ value during autumn months (SON) but overall it remains below zero (Fig.7a). We recognised that the calibration parameter $(\gamma)$ accounted for the net groundwater exchange and the river discharge and surface runoff from the un-gauged area surrounding the lake, as well as uncertainties regarding the hydrological measurements. However, with the magnitude of the mean $\gamma$ value close to the peak evaporation in May as well as the dramatic shift from a positive value to a negative one during summer months, this underlines the seasonal changes in the lake hydrological processes.

With the mean $\gamma$ value close to zero during the winter months of the year (DJF) (Fig. 7a), the calibration suggested that the groundwater component as well as the surface runoff and river discharge from the un-gauged area has negligible impact on the lake water budget in this period. This is likely due to the severe cold winter conditions with the average monthly 
temperature below $-25^{\circ} \mathrm{C}$ (Fig. $7 \mathrm{~b}$ ). As a result of this, the lake is covered by approximately 1 $\mathrm{m}$ of ice and most rivers are frozen. In addition to the low precipitation rate $(<5 \mathrm{~mm} / \mathrm{month})$, it is expected that the change in the lake water budget during the winter period is negligible. As the temperature rises in the spring months (MAM) accompanied by the snowmelt and a slight increase of precipitation ( $<25 \mathrm{~mm} / \mathrm{month}$ ), the $\gamma$ value increases steadily and reaches its peak in May. Despite the fact that the evaporation also increases during spring months and reaches its peak in May, the calculation suggested that the water components from the un-gauged area as well as the increased river discharge provide a similar amount of water for the lake evaporation process. Thus, the increase of the lake water level during spring months is similar to the increase of precipitation (Fig. 7b). As snowmelt is a slow process, in addition to the low intensive precipitation pattern during spring months, these water components are likely to infiltrate into the groundwater and increase the groundwater discharge into the lake. Thus, groundwater discharge from the aquifers surrounding the lake is likely the dominant process for replenishing the lake during spring months.

Despite the substantial increase of precipitation during summer months (JJA), river discharge measurements show no/little increase of river discharge in June and July but a slight increase in August and September. The amount of increased river discharge is disproportional to the amount of precipitation during summer months (JJA) which contributes over $70 \%$ of annual precipitation (Fig. 6). The substantial decrease of the $\gamma$ value from a positive value to a negative one during summer months may indicate that the inflow from the area surrounding the lake continually declines within the summer months and eventually becomes a net negative input in August. This is likely a result of the increased evapotranspiration due to the high temperature as well as the rapid plant growth rate during summer months. The high evapotranspiration rate reduces the soil moisture and subsequently lowers the groundwater recharge rate in the summer months. As the peak lake level generally occurs in July each year, the continuous decline of the groundwater level in the area surrounding the lake reduces the amount of groundwater discharge into the lake. 
However, the negative $\gamma$ value in August and autumn months (SON) suggests that net water loss occurs from the lake during this period. Given the reported annual lake water abstraction of $27 \mathrm{Mm} / \mathrm{yr}$ [6], the negative water balance with a magnitude up to 55 $\mathrm{mm} /$ month (equivalent to $130 \mathrm{Mm}^{3} /$ month) suggests that the lake water abstraction or other man-made factors could not contribute to such a big monthly water deficit. The lake water deficit in August and autumn months (SON) can be as a result of the lake water discharge into the shallow aquifers along the south-eastern lake shore due to the decline of groundwater level. As no groundwater measurement data were available for this study, data from river discharge measurements from hydrological stations $F$ \& $H$ may be used as an alternative to interpret this result. The comparison of the available annual measurements of river discharge for a short period (1961-1970) at hydrological stations F \& H show a decrease of the Wuerxun River discharge with a factor of 0.83 at $\sim 100 \mathrm{~km}$ downstream. This decline takes place within the un-gauged areas in the south-eastern lake watershed. In addition to the recent dry-up of Xinkai Lake at the lake's eastern shore, this may indicate that the groundwater level in this area may be low, which leads to the lake water discharge into the aquifer of this area. However, it is difficult to be certain given the lack of groundwater level measurements. Another explanation for the lake water loss could be seepage from the lake body into groundwater at the north-eastern border towards the downstream basin of the Argun River. The continuous net negative groundwater contribution and the reduction of precipitation during autumn months lead to a further decline of the lake water level. Overall the lowest water level of the year is observed in winter months (DJF) of the year during the calibration period.

The water balance calibration over the period of 1963-1980 (Fig. 7a) shows a clear seasonal fluctuation of the water contribution from the un-gauged area surrounding the lake, with an annual net contribution to the lake of $220 \mathrm{Mm}^{3} / \mathrm{yr}$. This is about one-third of the reported value of $648 \mathrm{Mm}^{3} / \mathrm{yr}$ with $390 \mathrm{Mm}^{3} / \mathrm{yr}$ from groundwater discharge and $258 \mathrm{Mm}^{3} / \mathrm{yr}$ from the surface runoff and river discharge by a previous estimate [6]. Without a comprehensive 
groundwater monitoring programme around the lake area as well as a conservative tracer investigation, the uncertainty of these estimates is difficult to determine. Further studies are needed to address the seasonal fluctuation of the lake water balance, particularly the significant water deficit in the August-November period. A negative monthly water balance was also reported in a recent study of a closed lake in Argentina [43].

\subsubsection{Lake water level prediction and validation}

The water balance model (Eq. 7) was used to predict monthly lake water levels from 19812012. The validation of the model was conducted by comparing the model predictions with the available monthly satellite observations of the water level from 1979-2014. During the prediction period, the mean monthly calibration parameter $(\gamma)$ value (Fig. 7a) was used as a constant parameter value for each month of the year. Lake surface water discharge via the Xinkai River was not considered from November to February of the year in the prediction calculation. This is because the lake is frozen and covered by up to $1.3 \mathrm{~m}$ of ice during these months of the year. Due to the discontinuation of hydrological station $E$ in the early 1980 s, the lake water evaporation $(E)$ in the prediction period was estimated by the monthly average of the available pan-evaporation measurements from the meteorological and hydrological stations in the lake region with correction factors obtained in the calibration period.

Fig. 8 shows observed and modelled water levels over the last 50 years, which includes the calibration period. The results indicated that, with an $\mathrm{EF}_{216}$ (Eq. (7)) value of 0.88, the water balance model reproduced the monthly water level time series well over the calibration period. This suggests that the mean monthly calibration parameter $(\gamma)$ values of the year obtained from the model calibration represent well the monthly fluctuation of the water components from the un-gauged area surrounding the lake over the period. With the mean monthly calibration parameter values, the water balance model was used to reconstruct the monthly water levels from 1961 to 2012 using available river discharge, evaporation and precipitation measurements (Model 1, Fig. 8). The comparison of the model results and the 
satellite observations shows that overall the predicted lake water levels exhibit a similar trend as obtained by the satellite observations from 1992 to 2010 . Most of the predicted monthly water levels are within the uncertainty of the satellite observations for this period, with a Nash-Sutcliffe model efficiency index $\left(\mathrm{EF}_{229}\right)$ of 0.93 when compared with the mean satellite measurements. We acknowledge that the satellite measurements contain large uncertainties in some particular months. This is because there are limitations of the satellite radar altimetry when applied to measure the lake water level. Similar to the situations near the sea shorelines, some altimetry data waveforms may be contaminated at the measured locations close to the lake shoreline. These measurements could lead to a large uncertainty in mean monthly measurement. In addition, the altimetry measurements/are not evenly distributed over the lake. Each month the altimetry measurements have different measurement numbers in different locations. Nevertheless, the trend of the mean monthly lake water levels is consistent with the reported water levels as well as the previous T/P measurements $[12,22]$. Further comparison of the predicted lake water levels with a previous study [14] showed good agreement for the periods of 1981-1984 and 1991-1999 but our model predictions underestimated the water levels during the period of 1985-1990. However, it is difficult to evaluate the model predictions during the period of 1981-1992 as there were no valid lake water level measurements. The satellite measurements show that the previous study overestimated the decline of the water levels during the period of 19992003 (Fig. 8). Overall, the water balance model in this study made an excellent prediction of the lake water level during the period of $1992-2010$.

We note that there are some discrepancies between the model prediction and the satellite observation from August 2010 onwards. The model appears to overestimate the water level decline of $\sim 0.8 \mathrm{~m}$ by the end of 2012 . Interestingly, the starting time of the model underestimation of the lake water level was at the same time period of the completion of the water transfer engineering project from the Hailar River [44]. By the time of writing of this manuscript, we do not have information regarding whether the water transfer started 
immediately after the project completion in August 2010, nor at which transfer rate. But satellite images from Google Earth clearly show that there was water flow in the newly constructed channel in 2011. With the reported annual water transfer rate of $390 \mathrm{Mm}^{3} / \mathrm{yr}$ [44] and the annual lumped calibration of $288.8 \mathrm{~mm} / \mathrm{yr}$ (equivalent to $220 \mathrm{Mm}^{3} / \mathrm{yr}$ obtained during model calibration), a new annual water level was calculated by assuming that the water transfer started in the year 2011. The new estimated annual water levels show a similar trend to the satellite observations during the period of 2011-2012 (Model 2, Fig. 8). This suggests that the water transfer project prevented a further decline of water level of over 0.5 $\mathrm{m}$ by the end of 2012. The recent altimetry measurements also show a rapid increase of the lake water level since the end of 2012, and the water level reached $543.5 \mathrm{~m}$ asl by the end of 2014. Despite our best efforts to collect hydrological data including river discharge, panevaporation and water transfer rate, by the time of writing this manuscript we did not have this data for the model evaluation. Given the increase of precipitation and terrestrial water storage in 2013-2014 (Fig.3b \& Fig. 6), it is expected that the rapid increase of the lake water level in 2013-2014 was a combined result of the increases of precipitation, river discharge and water transfer from the engineering project.

\subsection{Key drivers of the lake water level fluctuations}

Linear regression was conducted to explore the relationships among the annual change of the lake water level, precipitation, evaporation and river discharge into the lake during the period of 1963-2010. During the 48-year analysis, the reported annual lake water level from the local meteorology station was used for the period of 1961-1978 where neither in-situ measurements nor the satellite observations were available. The regression analysis shows that the fluctuation of the water level has a moderate positive correlation to the river discharge (0.57), with a weak positive correlation to precipitation (0.34) and a very weak negative correlation to evaporation $(-0.13)$ (Table 2). This suggests that river discharge is the key driver of the lake water level fluctuations over the five decades among these three hydrologic components. As precipitation varied significantly over this period (maximum: 
$580 \mathrm{~mm} / \mathrm{yr}$, minimum: $140 \mathrm{~mm} / \mathrm{y}$, Fig. 3b), it is interesting to see that precipitation has a weak influence on the lake water level. The moderate and weak correlations between changes in the water level and river discharge and precipitation underline that the lake water level may be also influenced by other hydrological components. The groundwater and surface water components from the un-gauged area surrounding the lake could be one of the key hydrological components influencing the lake water level fluctuations over the years, which have been highlighted by the model calibration. However, it is very difficult to quantify their impact without field measurements. A weak positive correlation between precipitation and river discharge $\left(0.26\right.$, Table 2) suggests that runoff within the $\sim 150,000 \mathrm{~km}^{2}$ lake watershed is also influenced by other hydrological components. This is consistent with the results from the GLDAS/Noah model which revealed a strong correlation coefficient (0.74) between the modelled runoff and soil moisture within the lake watershed.

\section{Conclusions}

The analyses of hydrological and climatic data in the Hulun Lake region showed that over the last five decades the lake has experienced one wet (1981-1998) and two dry (1964-1980, 1999-2012) periods. The two dry periods resulted in the decline of the lake water level by 3 and $4 \mathrm{~m}$, respectively. The wet period brought the water level up to the recent highest level and increased the lake surface water outflow. The combined analysis of precipitation and river discharge for these three periods revealed that river discharge is sensitive to changes in precipitation. Results from the GLDAS/Noah model suggested that soil moisture within the lake watershed has a great influence on the river discharge via both subsurface and surface runoffs. During the wet period, subsurface runoff could contribute $30 \%$ of river discharge but this declines to $0 \%$ in the dry period. The regression analysis suggests that the variations of river discharge into the lake were the key driver for the lake water level fluctuation over the last five decades. This study also suggested that satellite altimetry observations can provide an alternative to in-situ permanent gauging stations to estimate the lake water level. 
Climatic data suggested that there have been variations in the climatic conditions over the last five decades, particularly with regard to the annual temperature which showed an increase of the mean temperature by $1.6^{\circ} \mathrm{C}$ for 20 consecutive years during the period of 1989-2008. Joint analysis of variations in temperature, wind speed, humidity and sunshine duration against pan evaporation showed a weak correlation between these climatic parameters and evaporation. However, the recent 6-consecutive-year decrease (2009-2013) of the pan evaporation below the five-decade average up to $490 \mathrm{~mm} / \mathrm{yr}$ suggests that further studies are needed to better understand the impacts on the pan evaporation variation. With the magnitude of the recent change in evaporation rate similar to the annual precipitation rate, this could result in significant changes in key hydrological components of the lake as well as the lake water quality.

The comparison of model prediction and the satellite altimetry observations confirmed that the monthly water balance model is capable of predicting the lake water level fluctuations over the last five decades. The model revealed that the water transfer engineering project did prevent the further decline of the lake water level, with a magnitude of over $0.5 \mathrm{~m}$ during the period of 2011-2012. Model calibration suggested that the groundwater component and surface runoff and river discharge from the un-gauged area surrounding the lake contributed $\sim$ net $210 \mathrm{Mm}^{3} / \mathrm{yr}$ (equivalent to $\sim 100 \mathrm{~mm} / \mathrm{yr}$ ) water inflows into the lake. A positive net contribution from groundwater discharge into the lake was found in March-June and a net groundwater contribution was found in August-November.

\section{Acknowledgement}

This research is indirectly supported by a research grant aided by the Irish Department of Communications, Energy and Natural Resources under the National Geoscience Programme 2007-2013, and partly supported by the National key Basic Research Program of China (2013CB733302) and the Major International (Regional) Joint Research Program of 
NSFC (41210006). The views expressed in this paper are the authors' own and do not necessarily reflect the views and opinions of the Minister of Communications, Energy and Natural Resources. GLDAS/NOAH data used in this study were acquired as part of the mission of NASA's Earth Science Division and archived and distributed by the Goddard Earth Sciences (GES) Data and Information Services Center (DISC). We acknowledge the contribution of the AE Prof. Balaji Rajagopalan and two anonymous reviewers in improving the final manuscript. 


\section{Appendix}

The Hampel X84 technique, unlike the arithmetic mean used in the traditional standard deviation method, uses the median value to measure the robustness of an estimator against outliers. The traditional method, for example, the sample mean $\bar{X}$ and variance $S^{2}$ of a sample $X_{N}=\left\{x_{i}\right\}_{i=1}^{N}$ gives a good estimation for data location and scatter if outliers do not contaminate the sample, i.e.,

$$
\bar{X}=\frac{\sum_{i=1}^{N} x_{i}}{N}, \quad S^{2}=\frac{\sum_{i=1}^{N}\left(x_{i}-\bar{X}\right)}{N-1}
$$

However, when a dataset contains outliers, the sample mean may deviate significantly in the event of a single out-of-scale observation. To robustly estimate the location and the scatter, the median and the median absolute deviation (MAD) are recommended:

$$
\operatorname{median}\left(X_{N}\right)=\frac{x_{\left[\frac{N+1}{2}\right]: N}+x_{\left[\frac{N}{2}\right]+1: N}}{2}
$$

where [.] is the function to "round-down" to the nearest integer and $x_{1: N}, \ldots, x_{N: N}$ are the order statistics of the sample $X_{N}$. The median estimator has a breakdown point of $50 \%$. Hampel et al. [28] suggested an identifier using the median to estimate data locations, and the MAD to estimate data standard deviations, i.e., $x_{i}$ is identified as an outlier if

$$
\left|x_{i}-\operatorname{median}\left(X_{N}\right)\right| \geq 1.4826 \operatorname{MAD}\left(X_{N}\right)
$$

In this study, the outliers of the lake water level measurements within each month were detected by Hampel X84. After the removal of the outliers, the mean and the standard deviation of the measurements were used to represent the lake water level in each month. To ensure the stability of the measurements, at least three valid measurements after the removal of the outliers was required for each month. Otherwise, no valid measurements were considered for the month. 


\section{References}

[1] Wang Z. The Numerical Simulation of the Hulun Lake Watershed Hydrogology in Inner Mongolia under the Future Climate (in Chinese) [PhD Thesis]. Hohhot, PR, China: Inner Mongolia Agricultural University; 2012.

[2] Liu H, Y Yin, S Piao, F Zhao, M Engels, P Ciais. Disappearing Lakes in Semiarid Northern China: Drivers and Environmental Impact. Environmental Science \& Technology. 47 (2013) 12107-14, doi: 10.1021/es305298q.

[3] Tao S, J Fang, X Zhao, S Zhao, H Shen, H Hu, et al. Rapid loss of lakes on the Mongolian Plateau. Proceedings of the National Academy of Sciences of the United States of America. 112 (2015) 2281-6, doi: 10.1073/pnas.1411748112.

[4] Qin B, S Wang. Hulun Lake's recent changes and their responses to the climate. Journal of Arid Land Resources and Environment (in Chinese). 7 (1993) 1-9.

[5] Qin B, S Wang. The Recent Expansion of Hulun lake and Its Relation to Warming Global Climate. OCEANOLOGIA ET LIMNOLOGIA AINICA (in Chinese). 25 (1994) 280-7.

[6] Xu ZJ, FY Jiang, HW Zhao, ZB Zhang, L Sun. Annals of Hulun Lake. Jilin Literature and History Publishing House, 1989.

[7] Xue B, WC Qu, SM Wang, YMa, MD Dickman. Lake level changes documented by sediment properties and diatom of Hulun Lake, China since the late Glacial. Hydrobiologia. 498 (2003) 133-41, doi: 10.1023/a:1026275101174.

[8] Han X, C Yang. An Analysis of the Self-purification Function of Hulun Lake and its Effect on Regional Environmental Conservation. Jounral of Natural Resources (in Chinese). 17 (2002) 684-90.

[9] Yan D, Y He, W Deng, M Wang, C Wang. Influences of Eco-hydrological Process to Water Environmental System in Hulun Lake Basin. Bulletin of Soil and Water Conservation (in Chinese). 21 (2001) 1-5.

[10] Xiao J, Z Chang, R Wen, D Zhai, S Itoh, Z Lomtatidze. Holocene weak monsoon intervals indicated by low lake levels at Hulun Lake in the monsoonal margin region of 
northeastern Inner Mongolia, China. Holocene. 19 (2009) 899-908, doi:

10.1177/0959683609336574.

[11] Zhai D, J Xiao, L Zhou, R Wen, Z Chang, X Wang, et al. Holocene East Asian monsoon variation inferred from species assemblage and shell chemistry of the ostracodes from Hulun Lake, Inner Mongolia. Quaternary Research. 75 (2011) 512-22, doi:

10.1016/j.yqres.2011.02.008.

[12] Chen X, X Chuai, L Yang, H Zhao. Climatic warming and overgrazing induced the high concentration of organic matter in Lake Hulun, a large shallow eutrophic steppe lake in northern China. Science of the Total Environment. 431 (2012) 332-8, doi: 10.1016/j.scitotenv.2012.05.052.

[13] Chuai X, X Chen, L Yang, J Zeng, A Miao, H Zhao. Effects of climatic changes and anthropogenic activities on lake eutrophication in different ecoregions. International Journal of Environmental Science and Technology. 9 (2012) 503-14, doi: 10.1007/s13762-012-00662.

[14] Li C, W Ma, X Shi, W-G Liao. Reconstruction of the hydrology series and simulation of salinity in ungauged Lake Hulun. Journal of Lake Sciences (in Chinese). 18 (2006) 13-20. [15] Wang G, J Song, B-L Xue, X Xu, K Otsuki. Land Use and Land Cover Change of Hulun Lake Nature Reserve in Inner Mongolia, China: a Modeling Analysis. Journal of the Faculty of Agriculture Kyushu University. 57 (2012) 219-25.

[16] Li C, W Ma, B-S Ye, W-G Liao. Estimation of Water Evaporation and Water Balance in Ungauged Hulun Lake. Journal of China Hydrology (in Chinese). 26 (2006) 41-4.

[17] Alsdorf DE, JM Melack, T Dunne, LAK Mertes, LL Hess, LC Smith. Interferometric radar measurements of water level changes on the Amazon flood plain. Nature. 404 (2000) 174-7, doi: $10.1038 / 35004560$.

[18] Coe MT, CM Birkett. Calculation of river discharge and prediction of lake height from satellite radar altimetry: Example for the Lake Chad basin. Water Resources Research. 40 (2004), doi: W1020510.1029/2003wr002543. 
[19] Frappart F, K Do Minh, J L'Hermitte, A Cazenave, G Ramillien, T Le Toan, et al. Water volume change in the lower Mekong from satellite altimetry and imagery data. Geophysical Journal International. 167 (2006) 570-84, doi: 10.1111/j.1365-246X.2006.03184.x. [20] Zhang J, K Xu, Y Yang, L Qi, S Hayashi, M Watanabe. Measuring water storage fluctuations in Lake Dongting, China, by Topex/Poseidon satellite altimetry. Environmental Monitoring and Assessment. 115 (2006) 23-37, doi: 10.1007/s10661-006-5233-9. [21] Awange JL, E Forootan, J Kusche, JBK Kiema, PA Omondi, B Heck, et al. Understanding the decline of water storage across the Ramser-Lake Naivasha using satellite-based methods. Advances in Water Resources. 60 (2013) 7-23, doi: 10.1016/j.advwatres.2013.07.002.

[22] Hwang CW, MF Peng, JS Ning, J Luo, CH Sui. Lake level variations in China from TOPEX/Poseidon altimetry: data quality assessment and links to precipitation and ENSO. Geophysical Journal International. 161 (2005) 1-11, doi: 10.1111/j.1365-246X.2005.02518.x. [23] Rodell M, PR Houser, U Jambor, J Gottschalck, K Mitchell, CJ Meng, et al. The global land data assimilation system. Bulletin of the American Meteorological Society. 85 (2004) 381-+, doi: 10.1175/bams-85-3-381.

[24] Brutsaert W, M Sugita. Is Mongolia's groundwater increasing or decreasing? The case of the Kherlen River basin. Hydrological Sciences Journal-Journal Des Sciences Hydrologiques. 53 (2008) 1221-9, doi: 10.1623/hysj.53.6.1221.

[25] Davi NK, NPederson, C Leland, B Nachin, B Suran, GC Jacoby. Is eastern Mongolia drying? A long-term perspective of a multidecadal trend. Water Resources Research. 49 (2013) 151-8,doi: 10.1029/2012wr011834.

[26] Tsujimura M, Y Abe, T Tanaka, J Shimada, S Higuchi, T Yamanaka, et al. Stable isotopic and geochemical characteristics of groundwater in Kherlen River basin, a semi-arid region in eastern Mongolia. Journal of Hydrology. 333 (2007) 47-57, doi:

10.1016/j.jhydrol.2006.07.026. 
[27] Fu GB, CM Liu, SL Chen, EL Hong. Investigating the conversion coefficients for free water surface evaporation of different evaporation pans. Hydrological Processes. 18 (2004) 2247-62, doi: 10.1002/hyp.5526.

[28] Liu X, S Wang, Z Wu, Y Wang. Comparative analyses on two kinds of oberserved evaporation data in China. Quaterly Journal of Applied Meteorology (in Chinese). 9 (1998) $321-8$.

[29] Scharroo R, EW Leuliette, JL Lillibridge, D Byrne, MC Naeije, GT Mitchum. RADS: Consistent multi-mission products. Proceeding of the Symposium on 20 Years of Progress in Radar Altimetry, Venice, 20-28 September 2012. European Space Agency [Special Publication]2013. pp. 4.

[30] Scharroo R. RADS version 4.1.2 Data Manual. Delft University of Technology, Delft 2015.

[31] Joana Fernandes M, C Lazaro, AL Nunes, R Scharroo. Atmospheric Corrections for Altimetry Studies over Inland Water. Remote Sensing. 6 (2014) 4952-97, doi: $10.3390 /$ rs6064952.

[32] Hampel FR, EM Ronchetti, PJ Rousseeuw, WA Stahel. Robust Statistics - The Approach Based on Influence Functions. Wiley, 1986.

[33] Chen F, K Mitchell, J Schaake, YK Xue, HL Pan, V Koren, et al. Modeling of land surface evaporation by four schemes and comparison with FIFE observations. Journal of Geophysical Research-Atmospheres. 101 (1996) 7251-68, doi: 10.1029/95jd02165.

[34] Ek MB, KE Mitchell, Y Lin, E Rogers, P Grunmann, V Koren, et al. Implementation of Noah land surface model advances in the National Centers for Environmental Prediction operational mesoscale Eta model. Journal of Geophysical Research-Atmospheres. 108 (2003), doi: 885110.1029/2002jd003296.

[35] Syed TH, JS Famiglietti, M Rodell, J Chen, CR Wilson. Analysis of terrestrial water storage changes from GRACE and GLDAS. Water Resources Research. 44 (2008), doi: W0243310.1029/2006wr005779. 
[36] Tapley BD, S Bettadpur, JC Ries, PF Thompson, MM Watkins. GRACE measurements of mass variability in the Earth system. Science. 305 (2004) 503-5, doi:

10.1126/science.1099192.

[37] Watkins MM, DN Wiese, D-N Yuan, C Boening, FW Landerer. Improved methods for observing Earth's time variable mass distribution with GRACE using spherical cap mascons. Journal of Geophysical Research-Solid Earth. 120 (2015) 2648-71, doi: 10.1002/2014jb011547.

[38] Nash JE, JV Sutcliffe. River flow forecasting through conceptual models. Part 1-A discussion of principles. Journal of Hydrology. 27 (1970) 282-90.

[39] Bao G, Y Liu, N Liu, HW Linderholm. Drought variability in eastern Mongolian Plateau and its linkages to the large-scale climate forcing. Climate Dynamics. 44 (2015) 717-33, doi: 10.1007/s00382-014-2273-7.

[40] Roderick ML, LD Rotstayn, GD Farquhar, MT Hobbins. On the attribution of changing pan evaporation. Geophysical Research Letters. 34 (2007), doi:

L1740310.1029/2007gl031166.

[41] Longuevergne L, CR Wilson, BR Scanlon, JF Cretaux. GRACE water storage estimates for the Middle East and other regions with significant reservoir and lake storage. Hydrology and Earth System Sciences. 17 (2013) 4817-30, doi: 10.5194/hess-17-4817-2013.

[42] Li C, B-S Ye, W-G Liao, W Ma. Study on the water level variation and dried-up situation in Hulun Lake in 1900s. Journal of China Hydrology (in Chinese). 27 (2007) 43-5.

[43] Troin M, C Vallet-Coulomb, F Sylvestre, E Piovano. Hydrological modelling of a closed lake (Laguna Mar Chiquita, Argentina) in the context of 20th century climatic changes.

Journal of Hydrology. 393 (2010) 233-44, doi: 10.1016/j.jhydrol.2010.08.019.

[44] Huo W. China's great dispearing lake. 2011.

[45] Wang Z, C Li, W Li, S Zhang. Calculation and analysis of water balance in Lake Hulun, Inner Mongolia. Jounral of Lake Science (in Chinese). 24 (2012) 272-81. 
Tables 1

Table 1 Selected data from hydrological and meteorological stations for this study

\begin{tabular}{|c|c|c|c|c|c|c|}
\hline \multirow{2}{*}{$\begin{array}{l}\text { Station name } \\
\text { Hydrologic } \\
\text { station }\end{array}$} & \multirow{2}{*}{$\begin{array}{l}\text { Location } \\
\qquad \begin{array}{l}\text { (Lat \& } \\
\text { Lon) }\end{array}\end{array}$} & \multirow{2}{*}{$\begin{array}{l}\text { Elevation } \\
\text { (m asl) }\end{array}$} & \multicolumn{4}{|c|}{ Data } \\
\hline & & & Evaporation $^{\mathrm{a}}$ & River discharge & Lake wate & level \\
\hline Alatanemode & $\begin{array}{l}48^{\circ} 38^{\prime} \\
116^{\circ} 50^{\prime}\end{array}$ & 550 & 1996-2012 & 1963-2012 & $A$ & \\
\hline Kunduleng & $\begin{array}{l}48^{\circ} 04^{\prime} \\
117^{\circ} 45^{\prime}\end{array}$ & 576 & 1966-2012 & 1961-2012 & & \\
\hline Ganzhuhua & $\begin{array}{l}48^{\circ} 57^{\prime} \\
117^{\circ} 45^{\prime}\end{array}$ & 542 & NA & & & \\
\hline Dalai & $\begin{array}{l}49^{\circ} 08^{\prime} \\
117^{\circ} 22^{\prime}\end{array}$ & 593 & $1961-1980$ & & $1960-1$ & \\
\hline $\begin{array}{l}\text { Meteorological } \\
\text { station }\end{array}$ & & & & ) & SD & $\begin{array}{l}\text { Mean } \\
\text { WS }\end{array}$ \\
\hline Manzhouli & $\begin{array}{c}49^{\circ} 34^{\prime} \\
117^{\circ} 26^{\prime}\end{array}$ & 661.7 & NA & 196 & 2014 & \\
\hline $\begin{array}{l}\text { New barag } \\
\text { right banner }\end{array}$ & $\begin{array}{l}48^{\circ} 40^{\prime} \\
116^{\circ} 49^{\prime}\end{array}$ & 554.2 & $\begin{array}{l}1960-1965 \\
1974-2013\end{array}$ & 196 & 2014 & \\
\hline $\begin{array}{l}\text { New barag left } \\
\text { banner }\end{array}$ & $\begin{array}{l}48^{\circ} 13^{\prime} \\
118^{\circ} 16^{\prime}\end{array}$ & 642 & $\begin{array}{l}1960-1966 \\
1970-2013\end{array}$ & 196 & 2014 & \\
\hline Hailar & $\begin{array}{l}49^{\circ} 13^{\prime} \\
119^{\circ} 45^{\prime}\end{array}$ & 610.2 & & 196 & 2014 & \\
\hline
\end{tabular}

${ }^{a}$ Pan evaporation measurement, ${ }^{b}$ annual measurements. P: Precipitation; Mean T: mean temperature; $\mathrm{RH}$ : relative humidity; $\mathrm{SH}$. Sunshine duration; Mean WS: Mean wind speed. All data here are daily measurements unless otherwise stated.

Table 2. Pearson correlation coefficients among $\Delta h_{a}, P_{a}, E_{a}$ and $R_{s, a}$

\begin{tabular}{lccccc}
\hline & \multicolumn{6}{c}{$\boldsymbol{P}_{\boldsymbol{a}}$} & $\boldsymbol{E}_{\boldsymbol{a}, \boldsymbol{a}}$ \\
\hline Correction & $\Delta h_{a}$ & $\Delta \boldsymbol{h}_{\boldsymbol{a}}$ & & & \\
coefficient & $P_{a}$ & 0.34 & 1 & & \\
& $E_{a}$ & -0.13 & -0.18 & 1 & 1 \\
\hline & $R_{s, a}$ & 0.57 & 0.26 & 0.01 & \\
\hline
\end{tabular}

$\Delta h_{a}$ is the annual change of the water level, $P_{a}$ is the annual precipitation, $E_{a}$ is the annual evaporation, $R_{d, a}$ is the annual river discharge into the lake normalised to the lake area. 


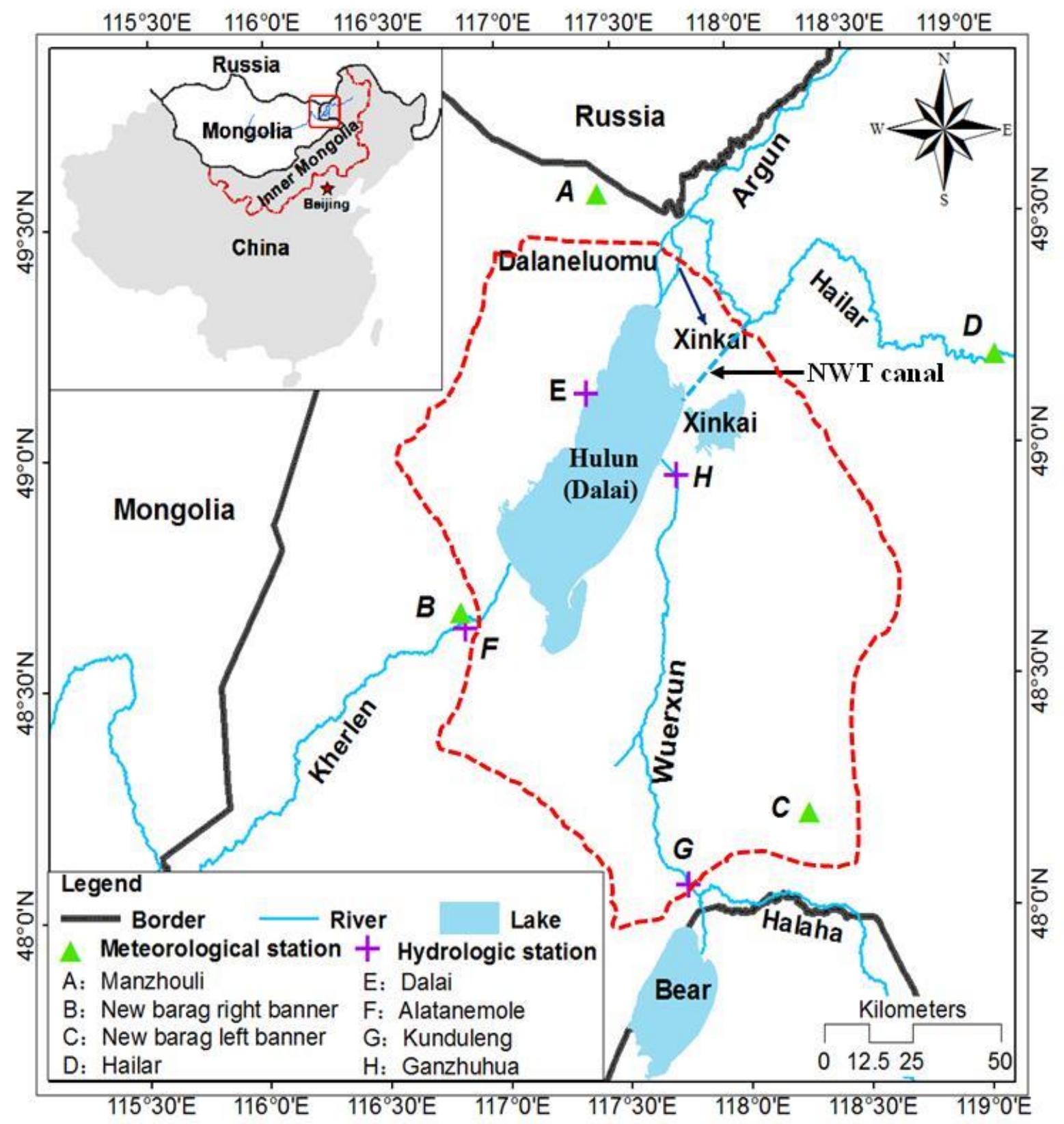

Fig. 1 Locations of Hulun Lake and its surrounding meteorological \& hydrological stations (after Wang et al. [45]). Red dashed line: un-gauged area around the lake delineated from DEM. NWT canal: new water transfer canal 


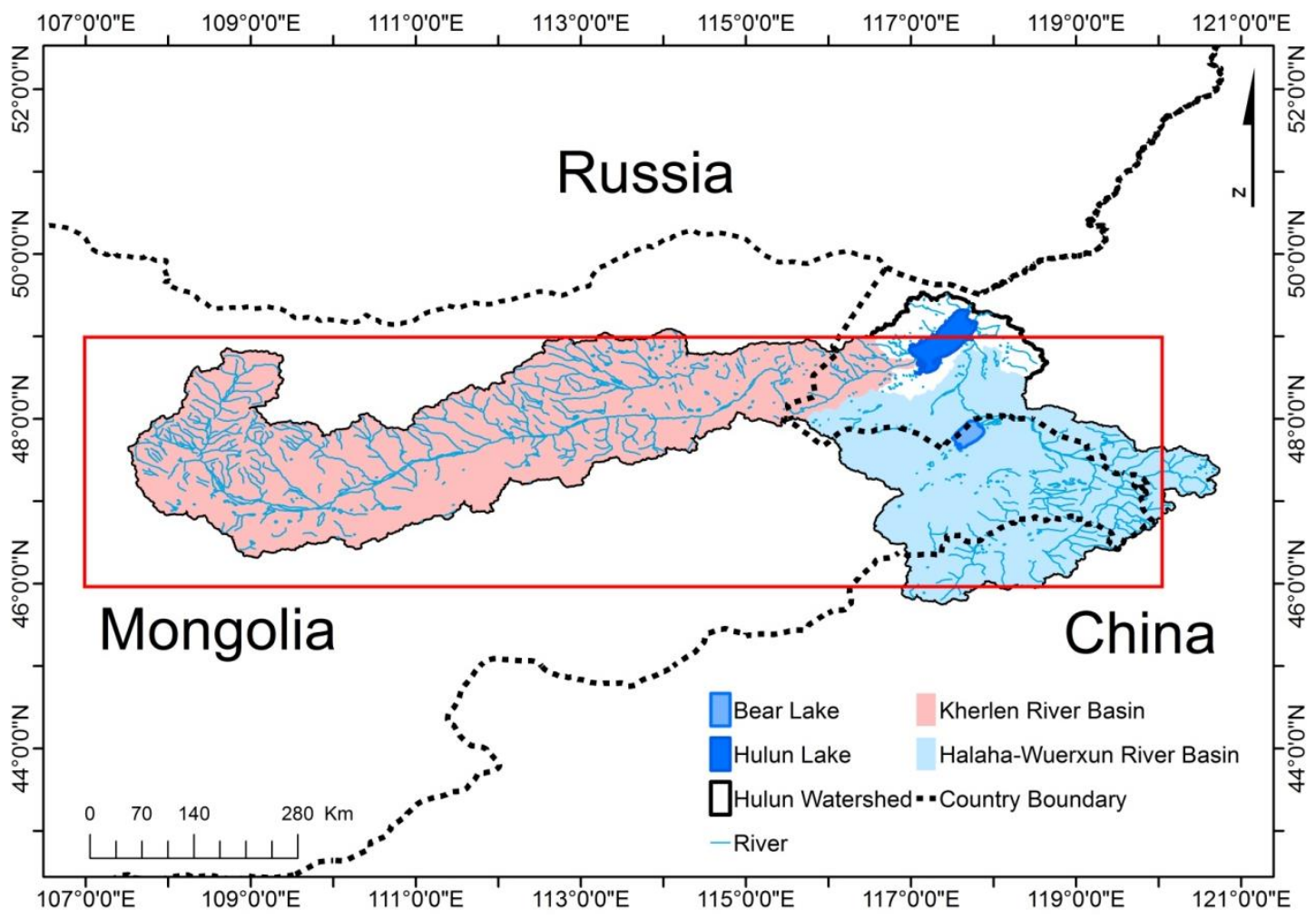

Fig. 2. The Hulun lake watershed and its river basins. The lake watershed and river basins were delineated by the DEM of the region. The GLDAS/Noah and GRACE data in the red box (latitude $\left[46^{\circ} 49^{\circ}\right]$, longitude $\left[107^{\circ} 120^{\circ}\right]$ ) were used in this study 

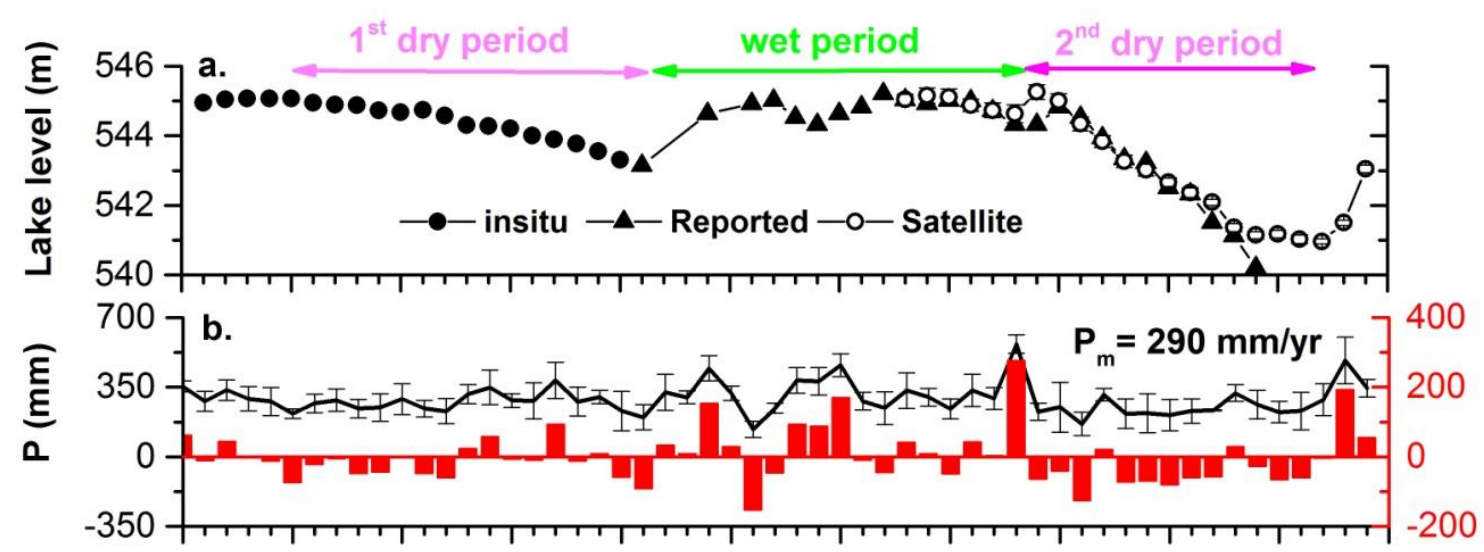

छิ

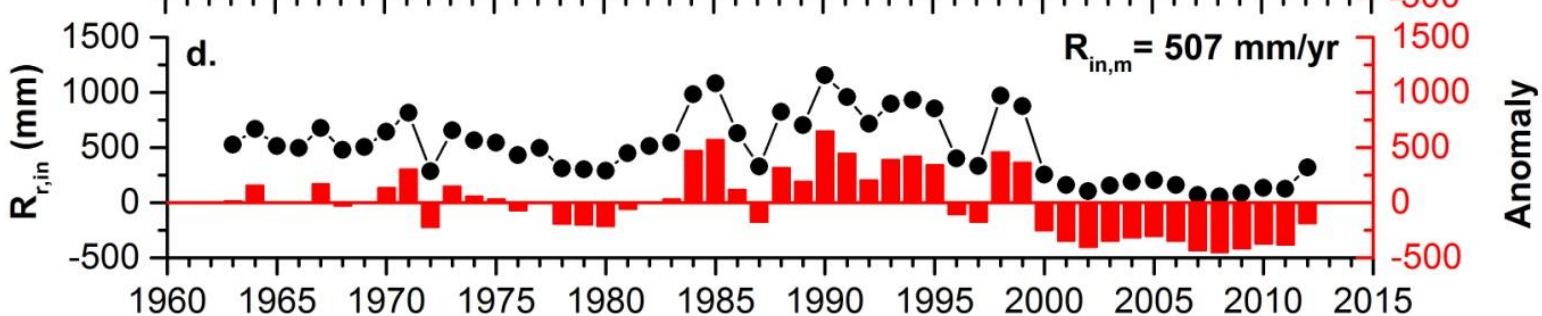

\section{Year}

Fig. 3 Over five decades of annual hydrological data of Hulun Lake: (a) Mean lake water level (above sea level): In-situ measurements from in-situ gauging stations, reported data were provided by the Meteorological Bureau of Hulun Lake [12], Satellite-Satellite altimetry measurement, (b) Precipitation $(P)$, (c) Pan-evaporation $\left(E_{\text {pan }}\right)$, (d) River influx rate $\left(R_{r, i n}\right)$ 

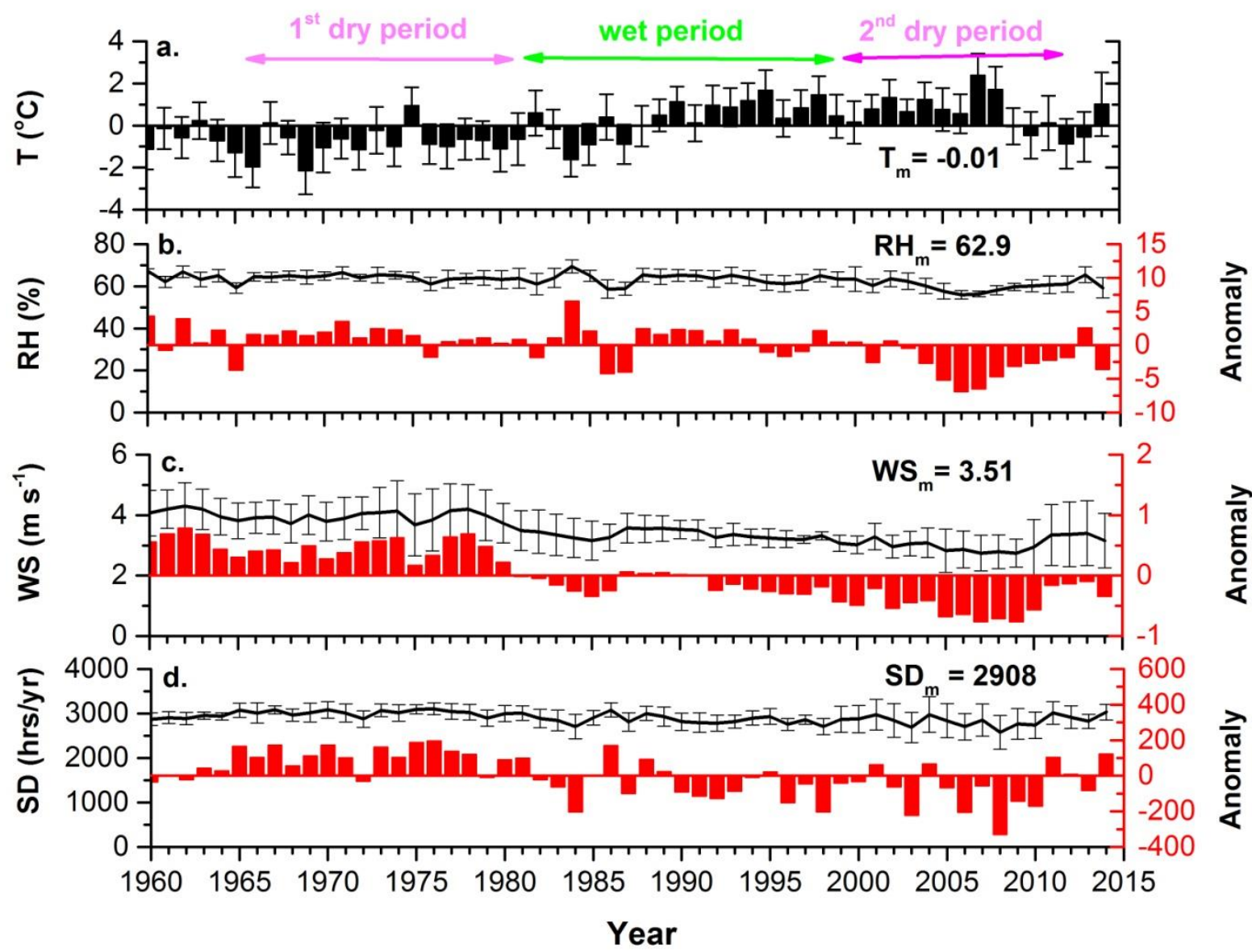

츤

Fig.4 Over five decades of annual climate data in the Hulun Lake region. (a) Annual temperature $(T)$, (b) Mean relative humidity $(R H)$, (c) Mean wind speed $(W S)$, (d) Annual sunshine duration $(S D)$ 


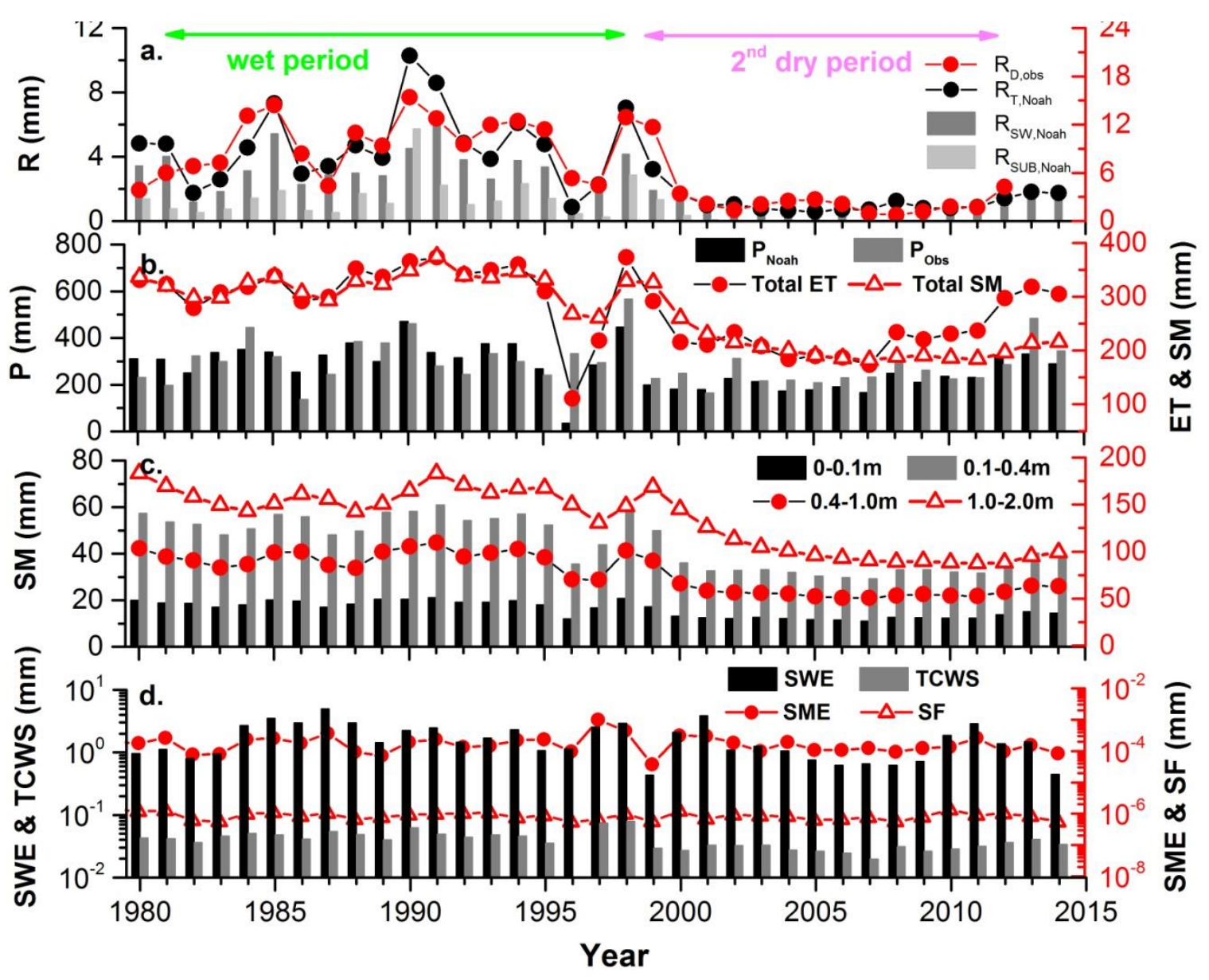

Fig. 5 Runoff $(R)$, precipitation $(P)$, total evapotranspiration (Total ET) and soil moisture (Total SM), snow water equivalence (SWE), total canopy water storage (TCWS), snowmelt (SME) and snowfall (SF) for the Hulun Lake watershed over the last 23 years. (a) Modelled and observed runoff: $R_{D, o b s}$, observed runoff-river discharge normalised to the lake watershed area $\left(150,000 \mathrm{~km}^{2}\right), R_{S W, \text { Noah }}, R_{S U B, \text { Noah }}$ and $R_{T, \text { Noah }}$ are the area-average surface, subsurface and total (surface +subsurface) runoff from the GLDAS/Noah model, respectively, (b) Total $E T$ and total $S M$, and precipitation rate $\left(P_{\text {Noah }}\right)$ from the GLADS/Noah model as well as precipitation $\left(P_{o b s}\right)$ observed at local meteorological stations, (c) Soil moisture distributed in the four model layers from the GLADS/Noah model, (d) Snow water equivalence, total canopy water storage, snowmelt and snowfall from the GLADS/Noah model 


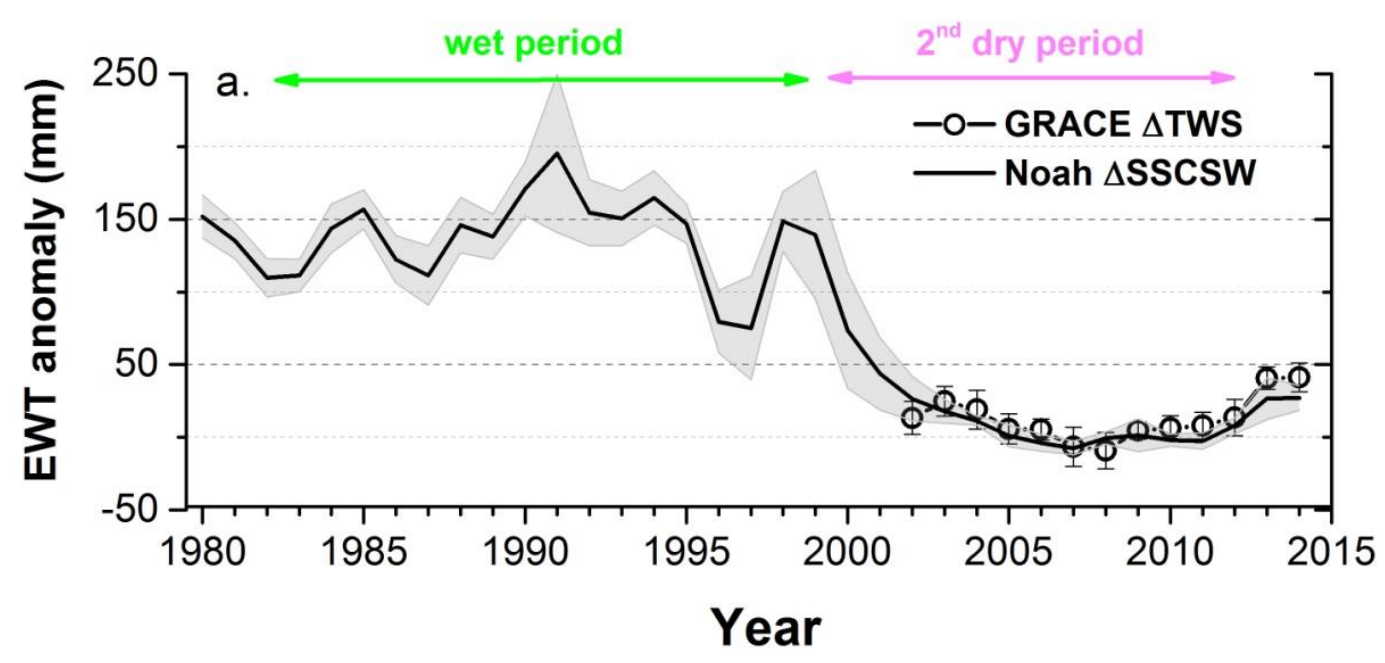

Fig. 6 Changes in annual terrestrial water storage determined by GRACE and the GLDAS/Noah model 

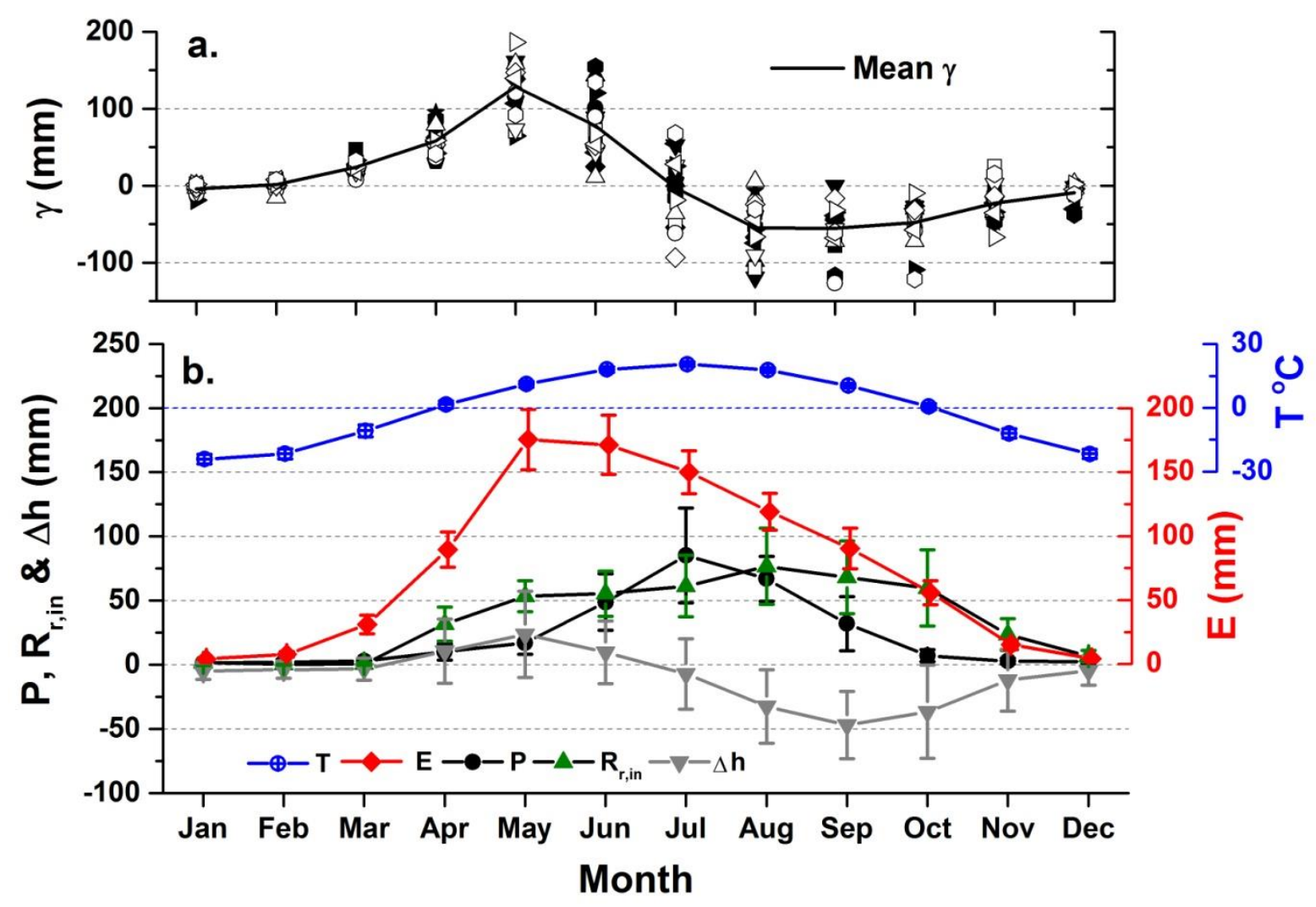

Fig. 7 Lake water balance model calibration over the years 1963-1960. (a) Monthly calibration parameter values $(\gamma)$ over a 17-year period and its averages, (b) Averages of monthly precipitation $(P)$, river influx rate $\left(R_{r, \text { in }}\right)$, lake evaporation rate $(E)$, water level change $(\Delta h)$ and temperature $(T)$ over the calibration period 


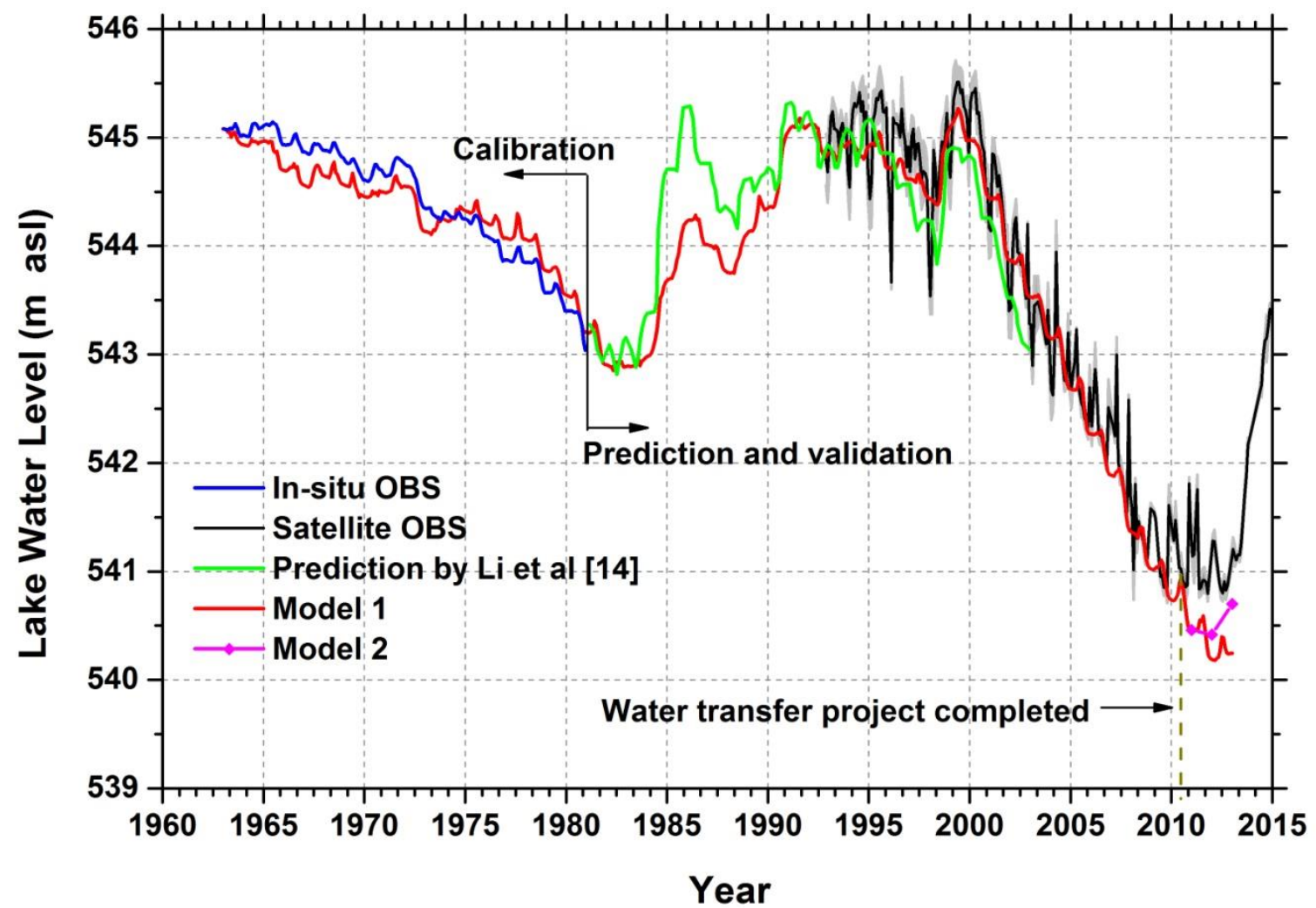

Fig. 8 Observed and predicted lake water level over the last five decades. In-situ OBS:

Observed monthly water level by the in-situ station. Satellite OBS: Observed monthly water level by satellite altimetry; the grey shading represents the measurement error. Model 1: Modelled monthly water level. Model 2: Modelled annual water level with the reported water diversion rate of $390 \mathrm{Mm}^{3} / \mathrm{yr}$ from the Hailar River 